\title{
Tracing Grog and Pots to Reveal Neolithic Corded Ware Culture Contacts in the Baltic Sea Region (SEM-EDS, PIXE)
}

\section{Holmqvist, Elisabeth}

2018-03

Holmqvist , E , Larsson, Å M , Kriiska , A, Palonen, V , Pesonen, P A P , Mizohata , K, Kouki , P \& Räisänen , J 2018 , ' Tracing Grog and Pots to Reveal Neolithic Corded Ware Culture Contacts in the Baltic Sea Region (SEM-EDS, PIXE) ' , Journal of Archaeological Science, vol. 91 , pp. 77-91 . https://doi.org/10.1016/j.jas.2017.12.009

http://hdl.handle.net/10138/307574

https://doi.org/10.1016/j.jas.2017.12.009

cc_by_nc_nd

acceptedVersion

Downloaded from Helda, University of Helsinki institutional repository.

This is an electronic reprint of the original article.

This reprint may differ from the original in pagination and typographic detail.

Please cite the original version. 


\title{
Author's Accepted Manuscript
}

Final published version of the article is available at

https://doi.org/10.1016/j.jas.2017.12.009

Journal of Archaeological Science 91 (2018) 77-91

\section{Tracing grog and pots to reveal neolithic Corded Ware Culture contacts in the Baltic Sea region (SEM-EDS, PIXE)}

\author{
Elisabeth Holmqvist, Åsa M. Larsson, Aivar Kriiska, Vesa Palonen, Petro Pesonen, Kenichiro Mizohata, Paula \\ Kouki, Jyrki Räisänen
}

\begin{abstract}
The Neolithic Corded Ware Culture (CWC) complex spread across the Baltic Sea region ca. 2900/2800$2300 / 2000$ BCE. Whether this cultural adaptation was driven by migration or diffusion remains widely debated. To gather evidence for contact and movement in the CWC material culture, grog-tempered CWC pots from 24 archaeological sites in southern Baltoscandia (Estonia and the southern regions of Finland and Sweden) were sampled for geochemical and micro-structural analyses. Scanning electron micro-scopy with energy dispersive spectrometry (SEM-EDS) and particle-induced X-ray emission (PIXE) were used for geochemical discrimination of the ceramic fabrics to identify regional CWC pottery-manufacturing traditions and ceramic exchange. Major and minor element concentrations in the ceramic body matrices of 163 individual vessels and grog temper (crushed pottery) present in the ceramic fabrics were measured by SEMEDS. Furthermore, the high-sensitivity PIXE technique was applied for group confirmation. The combined pot and grog matrix data reveal eight geochemical clusters. At least five geochemical groups appeared to be associated with specific find locations and regional manufacturing traditions. The results indicated complex inter-site and cross-Baltic Sea pottery exchange patterns, which became more defined through the grog data, i.e., the previous generations of pots. The CWC pottery exhibited high technological standards at these latitudes, which, together with the identified exchange patterns and the existing evidence of mobility based on human remains elsewhere in the CWC complex, is indicative of the relocation of skilled potters, possibly through exogamy. An analytical protocol for the geochemical discrimination of grog-tempered pottery, and its challenges and possibilities, is presented.
\end{abstract}

\section{Introduction}

The Neolithic Corded Ware Culture (CWC) complex is one of the most debated cultural phenomena in European prehistory. The CWC complex spread across Northern Europe ca. 2900/2800 - 2300/2000 BCE (e.g., Carpelan, 2004; Czebreszuk, 2004;Kriiska, 2000; Larsson, 2009; Malmer, 2002; Piliciauskas et al.,2011), reaching its northernmost extent in southern Baltoscandia, i.e., modern-day southern Finland, Sweden, and Estonia (Fig. 1). The CWC introduced new material traditions, burial practices, settlement patterns and ways of life. Evidence of keeping domesticated ruminants has been observed in osteological data (Larsson, 2009; Lõugas et al., 2007; Malmer, 2002), and lipids, both dairy and carcass fats, have been identified in Finnish and Baltic CWC pottery (Alvarez Romero, 2010; Cramp et al., 2014). Pollen and macrofossil evidence dating to the CWC period has confirmed that cultivation occurred, at least in Estonia and Sweden (Brink, 2009; Kriiska, 2003, 2009; Malmer, 2002).

Models of how the CWC spread across Northeastern Europe have tended to favour either migration or diffusion, with little room for regional and local complexity. Ancient DNA has presented new evidence for prehistoric migrations into Europe, including southern Scandinavia and Estonia, during the third millennium BCE (e.g., Allentoft et al., 2015; Haak et al., 2015; Kristiansen et al., 2017; Lazaridis et al., 2014; Mathieson et al., 2015; Skoglund et al., 2014; Sundell, 2014; Vuorisalo et al., 2012). Isotope analysis has been used to 
explore the life histories of individuals, and CWC cemeteries in Germany, for instance, have shown a high degree of individual mobility, especially for women (e.g. Sjögren et al., 2016).

While these new analyses have provided an understanding of the general processes occurring in Europe at the time, the model is difficult to verify in Finland and Sweden due to the scarcity of well-preserved human CWC remains (Malmström et al., 2015). To reveal details about the regional and local processes that led to the establishment of the Corded Ware culture in southern Baltoscandia, we must combine the analysis of human remains with new ways of examining the material culture.

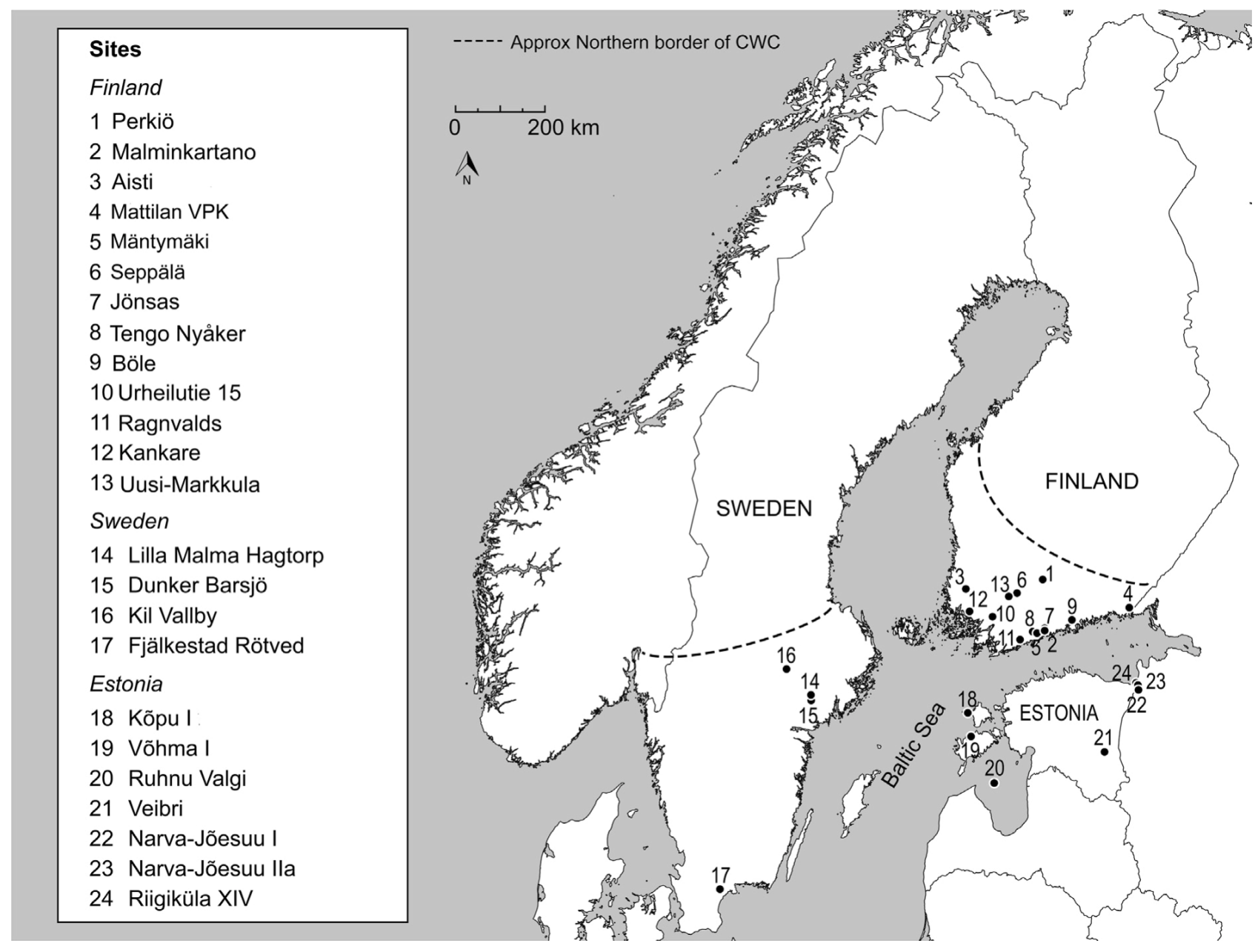

Fig. 1. The archaeological Corded Ware Culture sites in Finland, Sweden and Estonia, from which ceramic assemblages were sampled for this study, and the approximate Northern border of the CWC.

The CWC material cultures in Finland, Estonia and Sweden are clearly part of the European CWC complex, yet they also share stylistic similarities that set them apart from the Polish, German and Danish CWC. Both the pottery and battle axes exhibit stylistic elements peculiar to Baltoscandia (Larsson, 2009: 139-152; Lindström, 2003). People in the areas surrounding the Gulf of Finland were obviously in close contact during this period (Carpelan, 2004, 2006; Kriiska, 2000, 2009; Lang and Kriiska, 2007; Mökkönen, 2008, 2011; Nordqvist, 2016; Nordqvist and Häkälä, 2014). It has been suggested that the CWC first spread to East Sweden from Finland, rather than from Denmark or Poland, as was previously assumed (Larsson, 2008, 2009).

In Baltoscandia, CWC pottery was a novelty technologically as well: the early beakers were tempered with grog (crushed pottery) and were often fired in a reducing atmosphere (Edgren, 1970; Kriiska, 2000; Larsson, $2008,2009)$. This process suggests that they were produced by potters who were not merely imitating the new type of pottery using their traditional craft (cf. Beckerman, 2015). However, it remains unclear whether the early beakers were imported as prestige items or were manufactured locally by potters who had moved 
there from established CWC areas. This uncertainty raises the issue of discerning between pottery mobility versus potter mobility in a particular region.

\section{Group 1}

Böle KM22004:5911 Ragnvalds KM22397:9 Ragnvalds KM22397:354
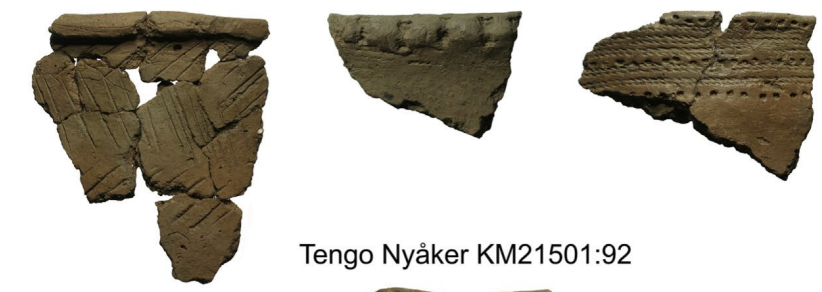

Tengo Nyåker KM21501:92
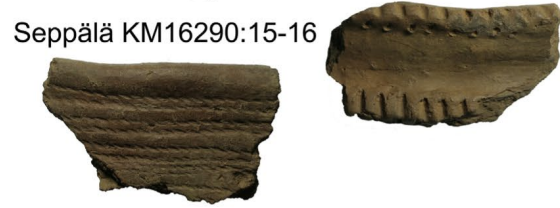

Tengo Nyåker KM21501:78

Group 2

Perkiö KM17073:177

Perkiö KM17281:149 Perkiö KM18047:297
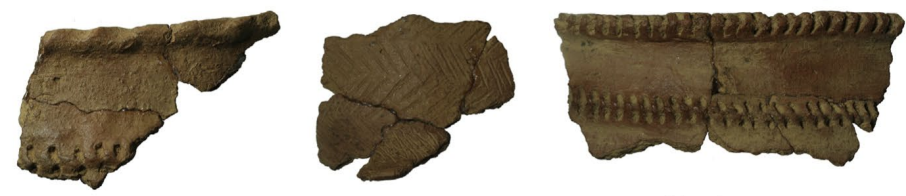

Perkiö KM17281:289

Perkiö KM18047:250

$$
\text { Kankare }
$$

KM23886:81

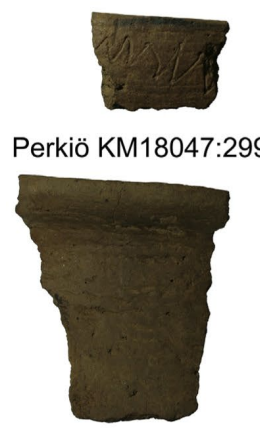

\section{Group 3}

Böle KM22004:6219

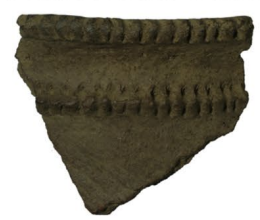

Kankare KM886:110

Urheilutie 15 KM22008:157
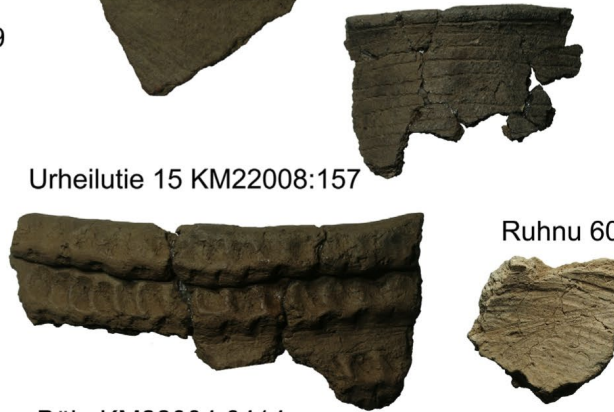

Ruhnu 60
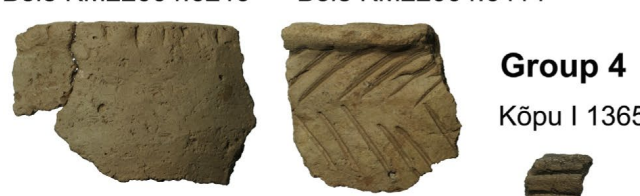

Kõpu I 1365
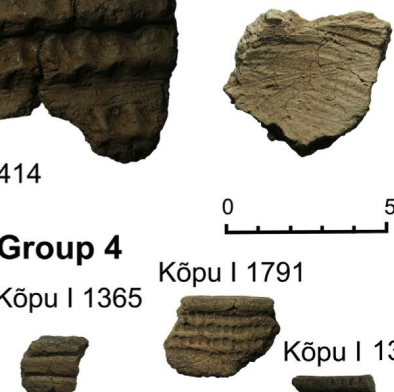

0 $5 \mathrm{~cm}$ Kõpu I 1791

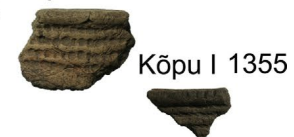

Fig. 2. CWC pottery sherds from sites in Finland and Ruhnu in Estonia, discussed in relation to geochemical groups 1-4.

\section{Research materials and chronology}

\subsection{Archaeological sites}

To characterise regional potting traditions and to identify possible cross-Baltic contacts between the CWC communities, we selected 163 ceramic sherds from 24 sites located in Finland, Estonia and Sweden (Fig. 1) for geochemical and micro-structural analyses. Altogether, 86 sherds (Figs. 2 and 3) suitable for invasive analysis were selected from well-stratified CWC deposits from 13 Finnish settlement sites, mostly located 
close to the southern coast, including Malminkartano in Helsinki, Jönsas in Vantaa, Tengo Nyåker in Kirkkonummi, Böle in Porvoo and Ragnvalds in Inkoo, among others (see Edgren, 1959, 1970; Nordqvist and Häkälä, 2014). Perkiö in Hämeenlinna is a presumed pottery production site (Carpelan, 1999: 264; Edgren, 1970) located further inland.

\section{Group 6}

Narva-Jõesuu lla Grave I

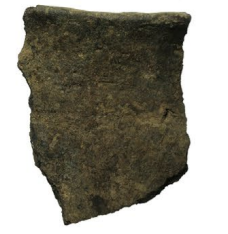

Fjälkestad Rötved 089880

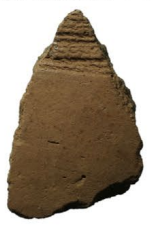

Vallby 1089866

\section{Group 7}

Narva-Jõesuu I

1786:90 Narva-Jõesuu Ila

F+. 2190:29 Narva-Jõesuu Ila

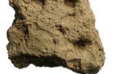

$2190: 73$

Riigiküla XIV

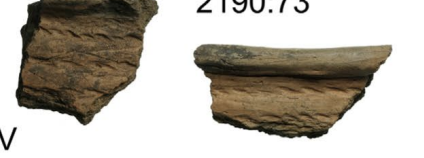

11261398

Fjälkestad Rötved

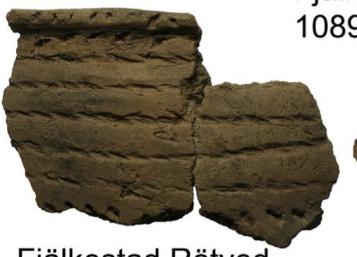
1089879

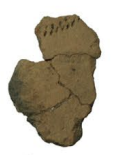

Fjälkestad Rötved

415581
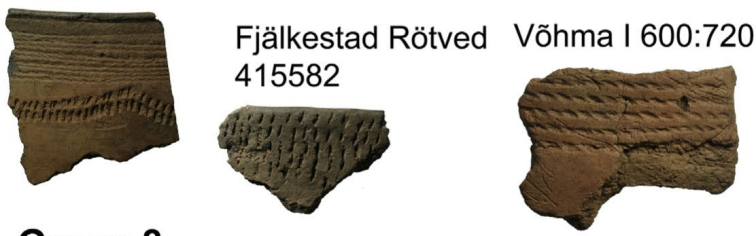

\section{Group 8}

Lilla Malma Hagtorp 1089874

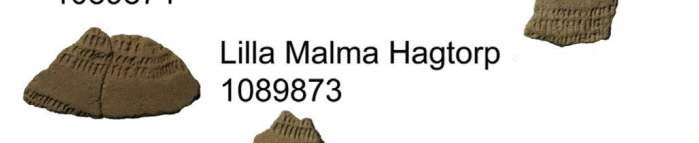

Dunker Barsjö
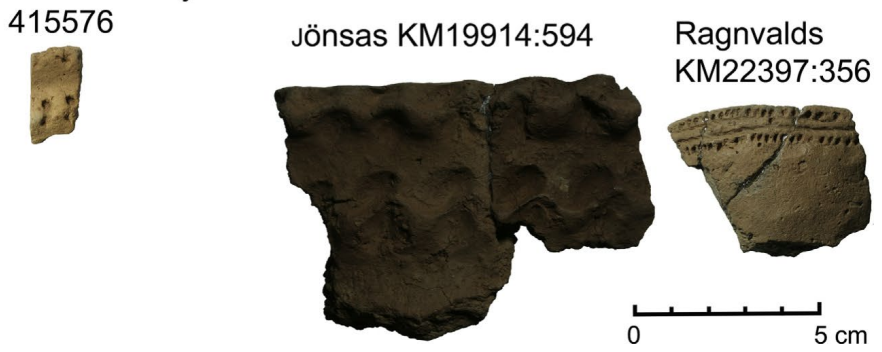

Fig. 3. CWC pottery sherds from Estonian and Swedish sites, and Jönsas and Ragnvalds in Finland, discussed in relation to geochemical groups 6-8. 
From Estonia, 54 sherds (Fig. 3) were sampled from clear CWC stratigraphic contexts recovered at seven recently excavated settlement sites. The sites represent three distinct geographic areas; the West Estonian islands Saaremaa (Võhma I), Hiiumaa (Kõpu I) and Ruhnu (Ruhnu Valgi); the coastal area of the mainland Northeastern part of Estonia (Riigiküla XIV, Narva-Jõesuu I, Narva-Jõesuu Ila); and the bank of the Emajõgi River (Veibri) in the inland Southeastern part of Estonia (see Kriiska, 2000, 2003; Kriiska et al., 2015).

From Sweden, 23 sherds from four sites were sampled (Fig. 3). Three sites are settlements in Eastern central Sweden, situated inland today although quite close to the coast at the time when Lake Mälaren was a deep bay of the Baltic Sea (see Larsson, 2009:139ff; Malmer, 1962, 2002). The fourth, Rötved Fjälkestad, is a burial site in Southernmost Sweden (Scania), situated inland but close to the east coast (Hansen, 1930; Malmer, 1962). While the CWC was eventually established all over South Sweden, the sites with the earliest pottery types are almost exclusively found along the eastern part facing the Baltic Sea, emphasising the probable connection to the CWC in Finland and the Baltic states (Larsson, 2009). The four Swedish sites were selected because the pottery found there belongs exclusively to the earliest phase of the CWC (Larsson, 2009: 139142). The Finnish and Estonian sites represent a broader chronological phase of the CWC period, because the pottery typology in these regions is more difficult to date due to a lack of well-preserved burials with diagnostic finds or well-dated short-term dwelling complexes.

\subsection{AMS dates}

We acquired eight new radiocarbon dates (from carbonised crust on pottery and burnt bone fragments) for CWC contexts in Finland and one from Sweden (Table 1). The original radiocarbon dates attained by Radiocarbon Analytics Finland, University of Helsinki and Ångström Laboratory, Uppsala University, were calibrated using Oxcal software version 4.2 (Bronk Ramsey, 2009, 2010; Palonen and Tikkanen, 2015), and the calibration curve was obtained using IntCal13 software (Reimer et al., 2013). The lipid composition of Finnish Corded Ware pots is mainly dairy fat or ruminant carcass fat (Cramp et al., 2014). If this trend holds for the samples dated in this study, the reservoir effect is probably negligent, although the slightly higher $\delta 13 C$-value in a sample from Mattilan VPK in Virolahti (Hela-3428, -23.5\%) could indicate a marine component in the crust (c.f. Kriiska et al., 2015: 43; Pesonen et al., 2012). Currently, there is no generally acknowledged method to perform reservoir correction in the Baltic Sea basin. The burnt bone samples (1-2 $\mathrm{g}$ fragments, all Mammalia indet.) were selected due to the extreme scarcity of datable materials in CWC contexts; however, they should represent the age of the wood burned in the pyre (Hüls et al., 2010; Olsen et al., 2012; van Strydonck et al., 2010).

The earliest stages of the CWC phenomenon in Denmark and Central Europe can be dated to ca. 3000-2900 cal BCE. The vast majority of the acquired dates are younger than $2800 \mathrm{cal}$ BCE and are as young as 2100 2000 cal BCE (Furholt, 2003; Włodarczak, 2009). Some Central European dates are controversial, and inconsistencies appear to exist between laboratories (Włodarczak, 2009). In the eastern Baltic region, the radiocarbon dates linked to the beginning of the CWC fall between 3000 and $2800 \mathrm{cal}$ BCE and span until at least ca. 2000 cal BCE (Kriiska et al., 2007, 2016: 109; Lõugas et al., 2007). In Sweden, the majority of the CWC-related dates span from 3000 to 2000 cal BCE (Brink, 2009). At the Rötved Fjälkestad cemetery in Sweden, the early-type beaker analysed in this project had a carbonised crust that was $14 \mathrm{C}$ dated to 2880 2670 cal BCE.

In previous studies, the CWC in Finland was dated to 3200-2350 cal BCE (Carpelan, 1999: 273) and later to 2900 e2250 cal BCE (Mökkönen, 2011: 17), following some controversy related to CWC-associated dates that appeared too old, compared to the continental European dates (Carpelan, 1999: 48, 2004; Edgren, 1993: 92; Jungner and Sonninen, 1983: 24, 32; Leskinen and Pesonen, 2008; Ojonen, 1983: 7; Purhonen, 1986). According to our new dates, the beginning of the CWC in Finland likely occurred at approximately 2900-2800 cal BCE. As suggested by Mökkönen (2011), the whole CWC sequence can be dated to ca. 2900-2250 cal BCE. 


\begin{tabular}{lllllll}
\hline Site & Collection no & Lab no & BP & Error & ô13C (\%) & calBCE (95,4\%) \\
\hline Korteslampi & KM18921 & Hela-3429 & 4216 & 28 & -28.0 & $2903-2696$ \\
Böle & KM22004:6006 & Hela-3426 & 4210 & 29 & -26.4 & $2900-2679$ \\
Mattilan VPK & KM15329:132 & Hela-3428 & 4136 & 29 & -23.5 & $2873-2620$ \\
Mäntymäki & KM16288:16 & Hela-3425 & 3897 & 29 & -28.9 & $2469-2297$ \\
Fjälkestad Rötved & SHM22057 1089883 & Ua-49016 & 4173 & 43 & -29.8 & $2889-2626$ \\
Tengo Nyåker & KM21501:51 & Hela-3461 & 4205 & 31 & -25.9 & crust \\
Urheilutie 15 & KM22008:144 & Hela-3458 & 4194 & 28 & -28.0 & crust \\
Urheilutie 15 & KM22008:202 & Hela-3457 & 4040 & 30 & -26.9 & $2890-2678$ \\
Uusi-Markkula & KM37643: 495 & Hela-3462 & 4161 & 31 & -27.6 & burnt bone \\
\hline
\end{tabular}

Table 1. AMS radiocarbon dates acquired from eight CWC sites in Finland and a CWC burial in Sweden.

\section{Methods}

\subsection{Scanning electron microscopy}

Ceramic samples prepared as polished cross-sections were analysed via scanning electron microscopy with energy dispersive spectrometry (SEM-EDS) to perform micro-chemical ceramic matrix analyses of both the ceramic bodies and the grog temper and to examine ceramic micro-structures, mineral inclusions and other technological aspects. Grog-tempered CWC pottery is a complex material in terms of geochemical characterisation, due to the possibility of internal compositional contamination caused by the grog temper, i.e., grog composed of imported pots used in pottery manufacture at the destination. The grog, often greater than $2 \mathrm{~mm}$ in diameter (Fig. 4a) and applied in abundant quantities, would, if originating from an imported pot, alter the bulk chemical composition of the ceramic fabric by adding a "foreign" compositional factor (Freestone, 1982; Zuluaga et al., 2011).
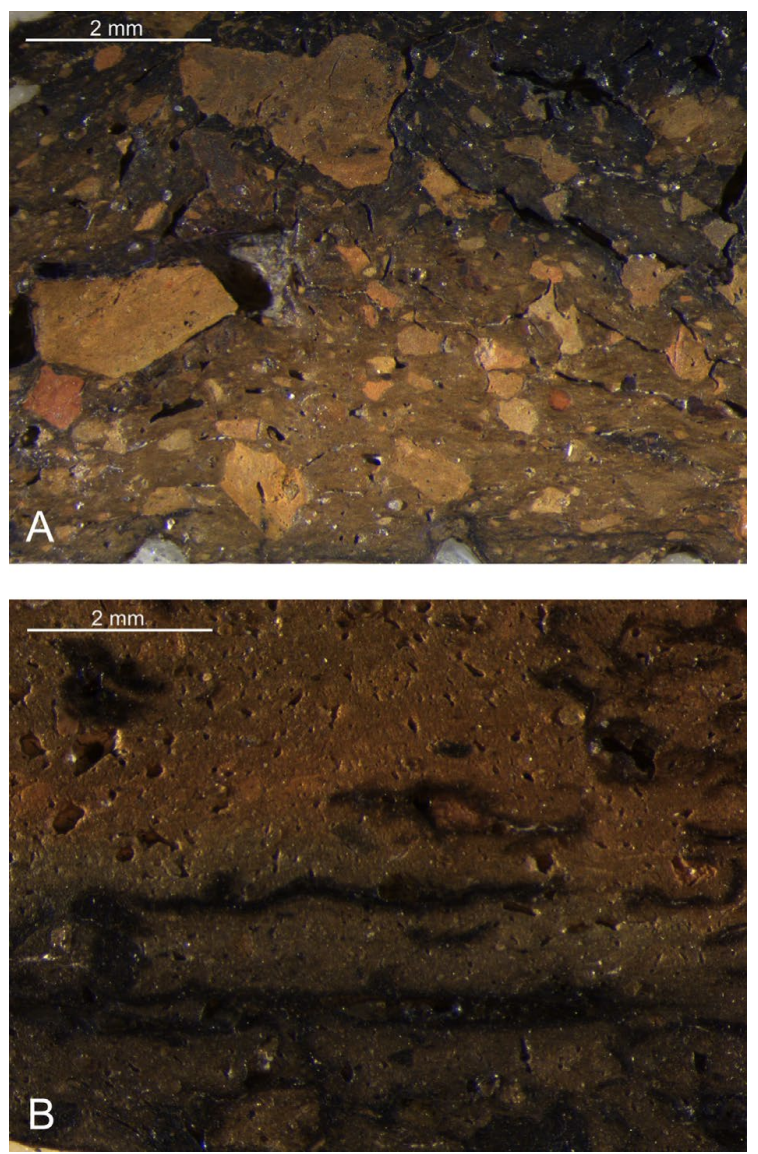

Fig. 4. Micrographs of ceramic cross-sections: a) sample KM22004:6006 from Böle, Finland, showing intensive grog tempering; b) sample NLM2181: 1227 with organic admixtures from Riigiküla XIV in Estonia. 
Hence, a typical analytical strategy for the geochemical grouping of ceramic materials, the preparation of a homogenised powder sample that represents the sample bulk composition, cannot be used for grogtempered pottery because it would not provide the ceramic recipe but instead possibly a mixture of recipes. Therefore, SEM-EDS was chosen as the primary analytical method to perform micro-chemical analyses and geochemical characterisation of both the grog and pot matrices separately under similar analytical conditions, thereby ensuring data consistency and comparability. Furthermore, elemental concentrations of the ceramic matrices can be considered more representative of the geochemistry of the original clay source exploited in pottery manufacture than ceramic fabric bulk analysis, especially in cases of heterogeneous fabrics (Buxeda i Garrigos et al., 2003: 14-15; Spataro, 2011; Zuluaga et al., 2011). Moreover, a correlation between ceramic matrix patterns and bulk chemistry compositions has been demonstrated (Holmqvist, 2010).

The analytical specimens were prepared by cutting a ca. $1.5 \mathrm{~cm}$ long cross-section of the pot wall mounted in epoxy resin blocks, polishing the sample with diamond pastes of different grades (down to a grain size of $0.25 \mathrm{~mm}$ ) following established procedures, washing it with IMA in an ultrasonic bath, and carbon coating the sample in a standard vacuum carbon sputter to ensure electrical conductivity. The instrument employed in this study was a FESEM-EDS instrument (Hitachi S-4800 with an Oxford Instruments 350 INCA energydispersive X-ray microanalysis system) at the Laboratory of Inorganic Chemistry at the University of Helsinki. Prior to the SEM analyses, the ceramic fabric cross-sections were examined under a stereomicroscope (Leica M80) to facilitate visual identification of the grog-fragments (Fig. 4a). Using SEM, grog can be recognised in the grey-scale backscattered electron (BSE) images (Fig. 5) as sub-angular shapes separated by voids from the clay mass, which is the fabric of the pot itself.

Inclusion-free areas of both the grog and sherd matrix were analysed to obtain elemental concentrations for both the clay mass used to make the pot itself and the clay mass used in the grog, representing a previous generation pot. For each matrix analysis, 3-5 measurements of areas sized 250-250 mm (500 x magnification; the measured area varied according to the size of the grog) were performed under the following conditions: a working distance of $15 \mathrm{~mm}$; an accelerating voltage of $20 \mathrm{kV}$; a process time of 5 , an equivalent of detector dead-time of ca. 30\%; and a time of acquisition of $180 \mathrm{~s}$. Non-plastic tempers, natural minerals, different grain sizes and voids indicative of organic temper were also examined in the ceramic fabrics. The semiquantitative measurements for $\mathrm{Na}, \mathrm{Mg}, \mathrm{Al}, \mathrm{Si}, \mathrm{P}, \mathrm{K}, \mathrm{Ca}, \mathrm{Ti}$ and Fe were checked for consistency, recalculated by stoichiometry as oxides using Oxford INCA software and reported as average weight percentage values of oxides. These data were subjected to hierarchical cluster analysis (CA) and principal component analysis (PCA) (Minitab, SPSS soft-ware; Baxter and Buck, 2000; Baxter and Freestone, 2006). $\mathrm{Na}_{2} \mathrm{O}$ as the lightest element and $\mathrm{P}_{2} \mathrm{O}_{5}$ for possible burial contamination (e.g., Schwedt et al., 2004) were excluded from the statistical analysis.

The data accuracy and precision were monitored by analysing two reference samples (SRM 679 Brick Clay and SRM 76a Burn Refractories) of known composition (Bishop et al., 1990: 539-542), measured as dried powder on carbon tape. For precision tests, coefficients of variation were calculated for the total of 14 runs perstandard acquired on seven separate days (Table 2). The tests showed acceptable precision values, with relative variation co-efficients of $<10$ or $<20 \%$ for most of the oxides. The coefficients of variation were slightly higher for oxides present in concentrations of ca. $1 \%$ or lower, i.e., close to the limit of detection (LOD) of the instrument. Consequently, only measured values $>0.2 \%$ are reported. For accuracy tests, the average results of the 14 runs were compared to the certified values of the standards. For SRM 679, the relative errors for $\mathrm{SiO}_{2}$ and $\mathrm{Fe}_{2} \mathrm{O}_{3}$ were $\leq 10 \%$ and $\leq 20 \%$ for all of the other oxides. For SRM $76 a$, the relative errors were $<10 \%$ for all of the oxides.

\subsection{Particle-induced $X$-ray emission}

The ceramic cross-sections prepared for the SEM-EDS analysis were subjected to particle-induced X-ray emission (PIXE) analysis (see Rizzutto and Tabacniks, 2017) employing the newly developed external beam PIXE setup at the Department of Physics, Accelerator Laboratory, University of Helsinki. The aim of the PIXE analysis was to broaden the elemental range for geochemical discrimination and to provide high-accuracy 
trace elemental data to evaluate the data structures indicated by the major and minor elemental SEM-EDS data. The main design features of the PIXE setup were: (i) the ability to use high total beam currents with rather low beam current density, thereby enabling reasonable measurement times with good detection sensitivity and a reduced risk of beam-induced sample damage; and (ii) the ability to analyse large sample areas (beam spot size up to $4 \mathrm{~mm}$ in diameter on the sample) without the need to scan the beam over the sample, thereby providing better composition averaging for inhomogeneous samples. The PIXE experimental setup includes a Be windowed $\mathrm{Si}(\mathrm{Li}) \mathrm{X}$-ray detector. The X-ray detector has an area of $100 \mathrm{~mm}^{2}$ and a resolution of $150 \mathrm{eV}$ (at $5.9 \mathrm{keV}$ ), and it was placed at $135^{\circ}$ relative to the direction of the beam (a detailed description of the experimental setup can be found in Palonen et al., 2016).
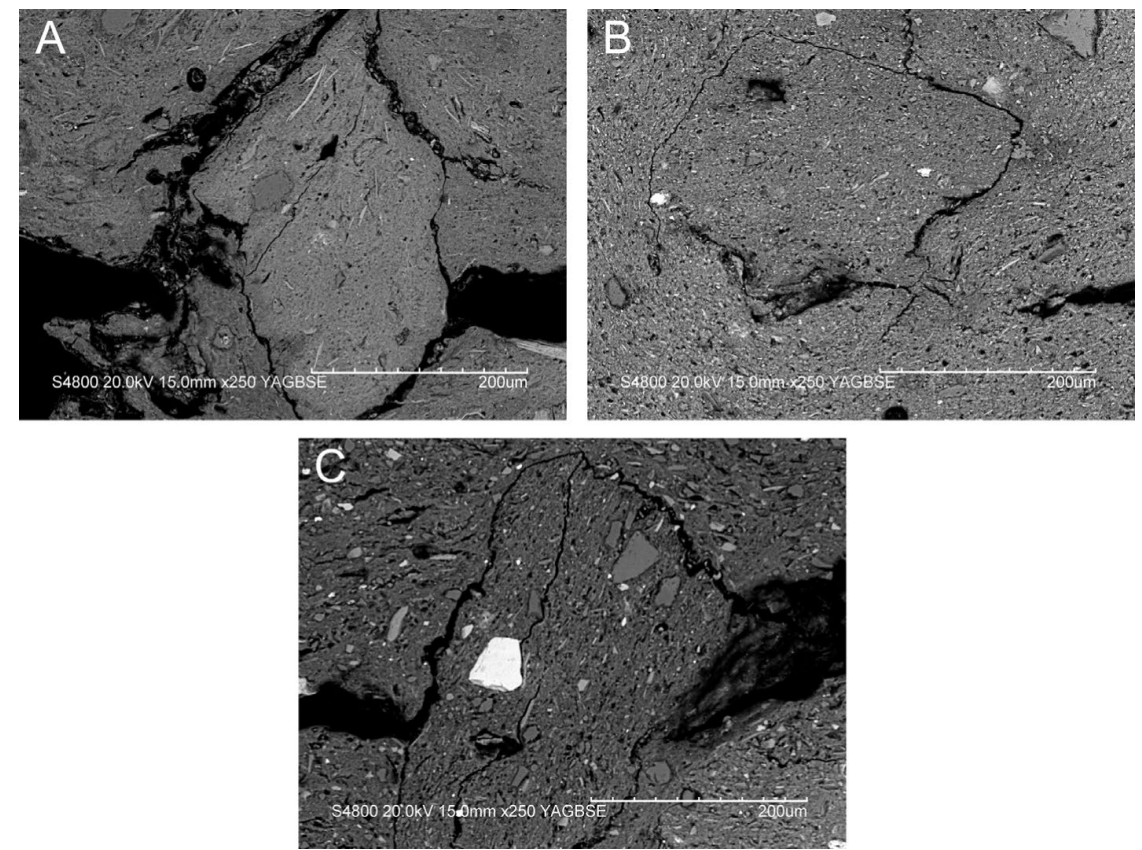

Fig. 5. Backscattered electron images of grog-temper in ceramic fabrics: a) sample KM17281:271 from Perkiö, Finland; b) sample KM21501:86 from Tengo Nyåker, Finland; c) sample 22057: 2 1089881 from Rötved Fjälkestad, Sweden.

\begin{tabular}{|c|c|c|c|c|c|c|c|c|c|c|}
\hline & $\mathrm{Na}_{2} \mathrm{O}$ & $\mathrm{MgO}$ & $\mathrm{Al}_{2} \mathrm{O}_{3}$ & $\mathrm{SiO}_{2}$ & $\mathrm{P}_{2} \mathrm{O}_{5}$ & $\mathrm{~K}_{2} \mathrm{O}$ & $\mathrm{CaO}$ & $\mathrm{TiO}_{2}$ & $\mathrm{Fe}_{2} \mathrm{O}_{3}$ & $\mathrm{SrO}$ \\
\hline $\begin{array}{l}\text { SRM } 679 \text { Brick Clay } \\
\text { Certified }\end{array}$ & 0.18 & 1.25 & 20.80 & 52.07 & & 2.93 & 0.23 & 0.96 & 12.94 & \\
\hline $\begin{array}{l}\text { SEM-EDS measured } \mu(\mathrm{n}=14) \\
\sigma \\
\mathrm{CV} \\
\delta \text { abs } \\
\delta \mathrm{rel}(\%)\end{array}$ & $<$ LOD & $\begin{array}{r}1.58 \\
0.18 \\
11.08 \\
0.32 \\
20.50\end{array}$ & $\begin{array}{r}24.05 \\
2.64 \\
10.41 \\
3.24 \\
13.49\end{array}$ & $\begin{array}{r}57.18 \\
4.43 \\
7.34 \\
5.11 \\
8.94\end{array}$ & & $\begin{array}{r}3.50 \\
0.61 \\
16.50 \\
0.57 \\
16.24\end{array}$ & $\begin{array}{r}0.27 \\
0.14 \\
48.43 \\
0.04 \\
15.63\end{array}$ & $\begin{array}{r}1.13 \\
0.36 \\
30.56 \\
0.17 \\
14.83\end{array}$ & $\begin{array}{r}11.79 \\
2.26 \\
18.20 \\
-1.15 \\
-9.79\end{array}$ & \\
\hline $\begin{array}{l}\text { SRM 76a Burn Refractories } \\
\text { Certified }\end{array}$ & 0.77 & 0.52 & 38.70 & 54.90 & 0.12 & 1.33 & 0.22 & 2.03 & 1.60 & 0.04 \\
\hline $\begin{array}{l}\text { SEM-EDS measured } \mu(\mathrm{n}=14) \\
\sigma \\
\mathrm{CV} \\
\delta \text { abs } \\
\delta \text { rel }(\%)\end{array}$ & $<$ LOD & $\begin{array}{r}0.55 \\
0.10 \\
18.23 \\
0.03 \\
6.18\end{array}$ & $\begin{array}{r}36.51 \\
1.36 \\
3.59 \\
-2.19 \\
-5.66\end{array}$ & $\begin{array}{r}57.09 \\
1.53 \\
2.59 \\
2.19 \\
3.99\end{array}$ & $<$ LOD & $\begin{array}{r}1.40 \\
0.16 \\
10.84 \\
0.07 \\
5.42\end{array}$ & $\begin{array}{r}0.22 \\
0.05 \\
22.94 \\
0.00 \\
-1.62\end{array}$ & $\begin{array}{r}2.28 \\
0.38 \\
16.08 \\
0.25 \\
12.42\end{array}$ & $\begin{array}{r}1.67 \\
0.51 \\
29.54 \\
0.06 \\
4.06\end{array}$ & \\
\hline $\begin{array}{l}\text { PIXE measured } \mu(\mathrm{n}=3) \\
\sigma \\
\mathrm{CV} \\
\delta \text { abs } \\
\delta \mathrm{rel}(\%)\end{array}$ & & & & & & $\begin{array}{r}1.21 \\
0.12 \\
10.13 \\
-0.12 \\
-9.02\end{array}$ & $\begin{array}{r}0.19 \\
0.02 \\
8.35 \\
-0.03 \\
-13.64\end{array}$ & $\begin{array}{r}1.97 \\
0.17 \\
8.55 \\
-0.06 \\
-3.20\end{array}$ & $\begin{array}{l}1.64 \\
0.09 \\
5.67 \\
0.04 \\
2.37\end{array}$ & $\begin{array}{l}0.04 \\
0.00 \\
9.13 \\
0.00 \\
2.70\end{array}$ \\
\hline
\end{tabular}

Table 2. Precision and accuracy data of the SEM-EDS of certified reference materials SRM 679 Brick Clay and SRM $76 a$ Burn Refractories and PIXE of SRM 76a. The measured SEM-EDS values (only values $>0.2$ wt \% are reported) are represented by the arithmetic mean $(\mu)$ of 14 consecutive runs on seven different days, and the PIXE values are arithmetic means $(\mu)$ of 3 consecutive runs. Certified values are given as references. The differences are given as both absolute ( $\delta$ abs) and relative ( $\delta$ rel, in \%) errors. 
The samples were measured with an $\mathrm{H}^{+}$beam with an energy of $3 \mathrm{MeV}$ obtained from the $5 \mathrm{MV}$ tandem accelerator of the university. The measurement times were $900 \mathrm{~s}$, corresponding to approximately $0.5 \mu \mathrm{C}$ of accumulated charge with typical beam currents of $0.5 \mathrm{nA}$. The collected X-ray spectrawere evaluated using AXIL software. For calibration and validation of the PIXE analytical procedure, SRM 679 (Brick Clay) was used as the main standard. The secondary standard was SRM 76a. The uncertainty in the determination of the concentrations of the major elements (Ca-Ti) was typically $0.3-2 \%$ and that of the minor and trace elements was $4-20 \%$ (Table 2).

\section{Results and discussion}

\subsection{Geochemical groups and indicated CWC pottery manufacturing regions and exchange}

The geochemical data set acquired by SEM-EDS consisted of 407 results, including 163 sherd matrices and 244 grog matrices. The data patterns indicated by the CA of the SEM-EDS data included eight compositional clusters (Table 3; Fig. 6). Based on the sample distribution among these groups, at least five groups (Coastal Finland, Perkiö, Kõpu, Northeastern Estonia and Central Sweden) appear associated with specific sites and regions, likely representing production clusters of the CWC pottery. The elemental concentrations measured by PIXE for the 163 ceramic sherds showed a related data structure, as illustrated by PCA plots of the SEMEDS and PIXE data (Fig. 7, Table 4) and the CA dendrogram of the PIXE-measured trace elements As, Sr, V, Zn, $\mathrm{Co}, \mathrm{Sc}, \mathrm{Cu}, \mathrm{Ba}$, and $\mathrm{Ni}$, with find region-specific clusters (Fig. 8). These geochemical groups also show differences in the ceramic microstructures, clay processing, mineralogy and tempering. All of the analysed ceramic fabrics are of non-calcareous clay. The data set in general shows high $\mathrm{P}_{2} \mathrm{O}_{5}$ values, likely deriving from the acid soil conditions combined with $\mathrm{P}$ rich alkaline rock formations in coastal Finland and phosphate minerals and gabbros in central Sweden; $P$ enrichment in clays is also evident in the limestone regions on the Estonian side of the Baltic Sea.

Group 1 (coastal Finland) in the SEM-EDS CA dendrogram (Fig. 6) includes only Finnish samples, mainly sherds and grog from coastal Finland CWC sites (e.g., Böle, Tengo Nyåker, Ragnvalds, Mäntymäki, Fig. 2), added by a few examples from the inland sites. The pots in this group display a notably processed and clean, probably sieved ceramic micro-structure (Fig. 9), bimodal grain size distribution with small mineral grains naturally occurring in the clay (quartz, feldspars, mica, titanite, and iron oxides; $<100 \mathrm{~mm}$ ) and larger-diameter grog $(<2 \mathrm{~mm}$ ) and other non-plastic temper (quartz, $\mathrm{K}$ and $\mathrm{Na}$ feldspars, granite, and mica; $300-800 \mathrm{~mm}$ ). Based on the trace elemental PIXE data (Fig. 8), this group further divides into two groups, the first dominated by Böle finds and the latter by Ragnvalds. Groups 1 and 2 (Coastal Finland and Perkiö) associated with the Finnish region show higher $\mathrm{MgO}, \mathrm{Fe}, \mathrm{Co}$ and $\mathrm{Ni}$ values than the other samples (Tables 3 and 4).

\begin{tabular}{|c|c|c|c|c|c|c|c|c|c|c|}
\hline SEM-EDS & & $\mathrm{Na}_{2} \mathrm{O} \%$ & $\mathrm{MgO} \%$ & $\mathrm{Al}_{2} \mathrm{O}_{3} \%$ & $\mathrm{SiO}_{2} \%$ & $\mathrm{P}_{2} \mathrm{O}_{5} \%$ & $\mathrm{~K}_{2} \mathrm{O} \%$ & $\mathrm{CaO} \%$ & $\mathrm{TiO}_{2} \%$ & $\mathrm{FeO} \%$ \\
\hline Group 1 (Coastal Finland) & $\begin{array}{l}\mu(n=93) \\
\sigma\end{array}$ & $\begin{array}{l}1.53 \\
0.21\end{array}$ & $\begin{array}{l}4.04 \\
0.57\end{array}$ & $\begin{array}{l}20.21 \\
1.09\end{array}$ & $\begin{array}{l}55.12 \\
1.82\end{array}$ & $\begin{array}{l}1.66 \\
0.99\end{array}$ & $\begin{array}{l}4.77 \\
0.64\end{array}$ & $\begin{array}{l}1.32 \\
0.26\end{array}$ & $\begin{array}{l}1.18 \\
0.12\end{array}$ & $\begin{array}{l}10.18 \\
1.44\end{array}$ \\
\hline Group 2 (Perkiö) & $\begin{array}{l}\mu(n=57) \\
\sigma\end{array}$ & $\begin{array}{l}1.31 \\
0.41\end{array}$ & $\begin{array}{l}3.60 \\
0.52\end{array}$ & $\begin{array}{l}21.99 \\
1.23\end{array}$ & $\begin{array}{l}51.98 \\
1.89\end{array}$ & $\begin{array}{l}2.31 \\
1.98\end{array}$ & $\begin{array}{l}4.83 \\
0.56\end{array}$ & $\begin{array}{l}1.08 \\
0.19\end{array}$ & $\begin{array}{l}1.19 \\
0.11\end{array}$ & $\begin{array}{l}11.72 \\
2.00\end{array}$ \\
\hline Group 3 (Grog A) & $\begin{array}{l}\mu(\mathrm{n}=49) \\
\sigma\end{array}$ & $\begin{array}{l}120 \\
0.29\end{array}$ & $\begin{array}{l}3.74 \\
0.73\end{array}$ & $\begin{array}{l}19.54 \\
1.89\end{array}$ & $\begin{array}{l}51.39 \\
2.64\end{array}$ & $\begin{array}{l}1.80 \\
1.14\end{array}$ & $\begin{array}{l}5.91 \\
0.73\end{array}$ & $\begin{array}{l}1.33 \\
0.39\end{array}$ & $\begin{array}{l}1.47 \\
0.19\end{array}$ & $\begin{array}{l}13.50 \\
2.67\end{array}$ \\
\hline Group 4 (Kōpu) & $\begin{array}{l}\mu(n=19) \\
\sigma\end{array}$ & $\begin{array}{l}1.04 \\
0.26\end{array}$ & $\begin{array}{l}2.73 \\
0.54\end{array}$ & $\begin{array}{l}20.90 \\
1.33\end{array}$ & $\begin{array}{l}48.69 \\
2.38\end{array}$ & $\begin{array}{l}7.55 \\
1.54\end{array}$ & $\begin{array}{l}4.80 \\
0.36\end{array}$ & $\begin{array}{l}2.79 \\
0.66\end{array}$ & $\begin{array}{l}1.18 \\
0.16\end{array}$ & $\begin{array}{l}10.31 \\
1.33\end{array}$ \\
\hline Group 5 (Grog B) & $\begin{array}{l}\mu(\mathrm{n}=32) \\
\sigma\end{array}$ & $\begin{array}{l}1.21 \\
0.60\end{array}$ & $\begin{array}{l}3.21 \\
0.69\end{array}$ & $\begin{array}{l}19.09 \\
1.92\end{array}$ & $\begin{array}{l}47.99 \\
4.64\end{array}$ & $\begin{array}{l}1.95 \\
1.70\end{array}$ & $\begin{array}{l}4.24 \\
0.54\end{array}$ & $\begin{array}{l}0.90 \\
0.20\end{array}$ & $\begin{array}{l}1.22 \\
0.30\end{array}$ & $\begin{array}{l}20.00 \\
3.63\end{array}$ \\
\hline Group 6 (Estonia/Sweden) & $\begin{array}{l}\mu(n=22) \\
\sigma\end{array}$ & $\begin{array}{l}1.16 \\
0.47\end{array}$ & $\begin{array}{l}2.31 \\
0.38\end{array}$ & $\begin{array}{l}20.69 \\
1.44\end{array}$ & $\begin{array}{l}58.05 \\
1.62\end{array}$ & $\begin{array}{l}1.36 \\
1.11\end{array}$ & $\begin{array}{l}5.28 \\
0.75\end{array}$ & $\begin{array}{l}1.08 \\
0.34\end{array}$ & $\begin{array}{l}1.25 \\
0.28\end{array}$ & $\begin{array}{l}8.80 \\
1.40\end{array}$ \\
\hline Group 7 (NE Estonia) & $\begin{array}{l}\mu(n=74) \\
\sigma\end{array}$ & $\begin{array}{l}0.89 \\
0.54\end{array}$ & $\begin{array}{l}2.32 \\
0.38\end{array}$ & $\begin{array}{l}21.09 \\
1.36\end{array}$ & $\begin{array}{l}58.04 \\
2.77\end{array}$ & $\begin{array}{l}3.13 \\
1.67\end{array}$ & $\begin{array}{l}4.61 \\
0.58\end{array}$ & $\begin{array}{l}0.74 \\
0.29\end{array}$ & $\begin{array}{l}0.94 \\
0.18\end{array}$ & $\begin{array}{l}8.23 \\
1.68\end{array}$ \\
\hline Group 8 (Central Sweden) & $\begin{array}{l}\mu(\mathrm{n}=33) \\
\sigma\end{array}$ & $\begin{array}{l}1.40 \\
0.45\end{array}$ & $\begin{array}{l}2.61 \\
0.46\end{array}$ & $\begin{array}{l}18.30 \\
1.21\end{array}$ & $\begin{array}{l}60.63 \\
1.98\end{array}$ & $\begin{array}{l}1.89 \\
1.11\end{array}$ & $\begin{array}{l}4.67 \\
0.37\end{array}$ & $\begin{array}{l}1.15 \\
0.25\end{array}$ & $\begin{array}{l}0.98 \\
0.10\end{array}$ & $\begin{array}{l}8.37 \\
1.59\end{array}$ \\
\hline
\end{tabular}

Table 3. Group mean values $(\mu)$ and standard divisions $(\sigma)$ for the geochemical groups indicated by the CA of the SEMEDS data, including pot and grog matrix data, reported in normalised wt \% by stoichiometry. 


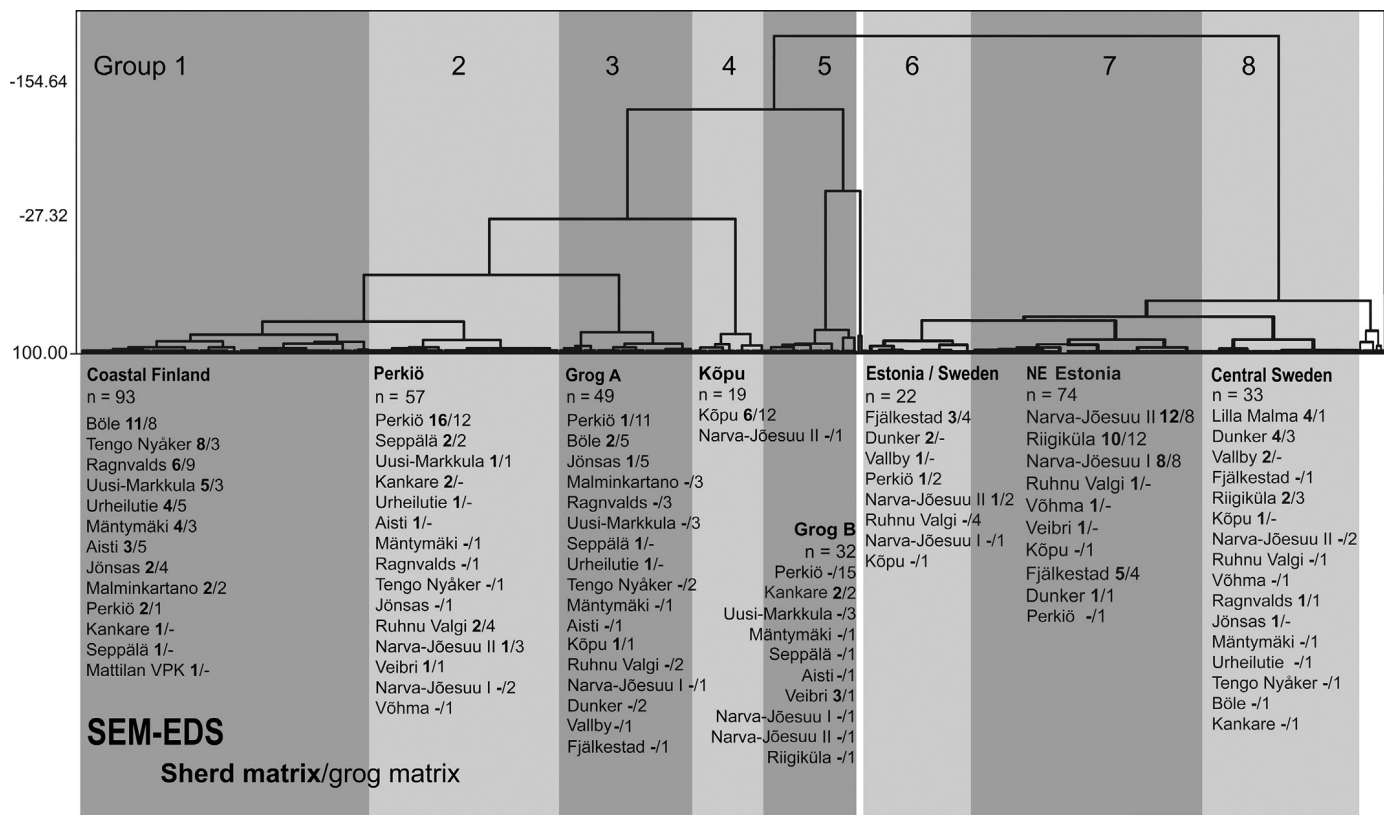

Fig. 6. Hierarchical CA dendrogram of the geochemical ceramic data acquired by SEM-EDS, including pot and grog matrix data (163 pot sherds and 244 analysed grog fragments).

The clay deposits on the Finnish coast, covered by the waters of the Baltic Sea during the isostatic land uplift after the last Glacial period, are affected by the weathering of the granitic bedrock (part of the Archean to Proterozoic Fenno-Scandian Shield) (Donner, 1991: 94; Korsman and Koistinen, 1998: 95-97; GTK, Bedrock of Finland; Salonen et al., 2002: 54). The high Fe and $\mathrm{Mg}$ concentrations in the samples likely reflect the presence of secondary clay minerals, such as vermiculite and illite, and the formation of Fe oxides in the oxidising conditions of the seabed, while $\mathrm{Ca}$ and $\mathrm{Ti}$ concentrations are low in clays on the Finnish coast (AlAni and Sarapää, 2008: 82; Donner, 1991: 94; Salonen et al., 2002: 56-57).
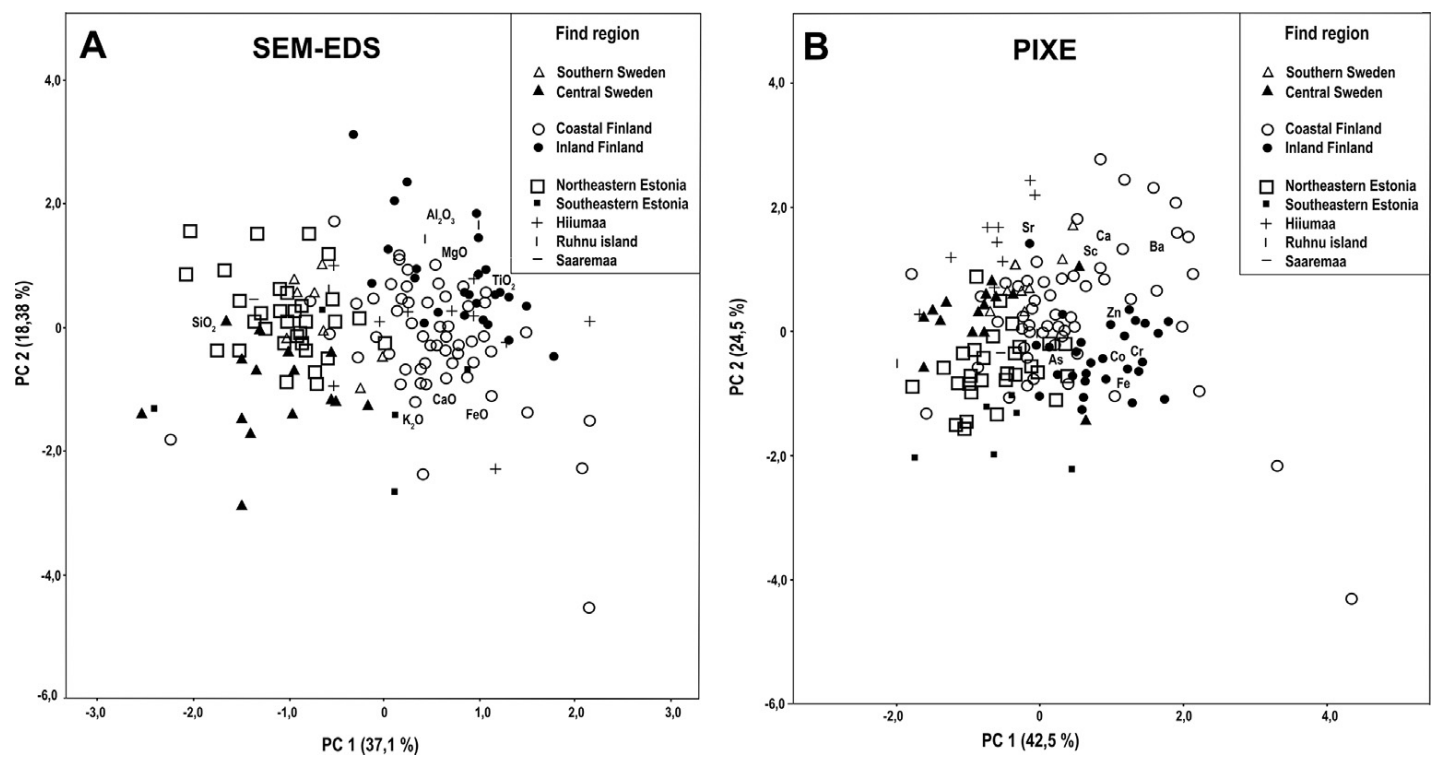

Fig. 7. PCA plots of the ceramic compositional data showing similar data patterns and find-region specific clusters: a) SEM-EDS measured elements $\mathrm{MgO}, \mathrm{Al2O}$, SiO2, $\mathrm{K2O}, \mathrm{CaO}$, TiO2, and $\mathrm{FeO}$; total variance for the first three components $71.2 \%$; b) PIXE measured elements $\mathrm{Fe}, \mathrm{Ca}, \mathrm{Ti}, \mathrm{As}, \mathrm{Sr}, \mathrm{Ba}, \mathrm{V}, \mathrm{Zn}, \mathrm{Co}, \mathrm{Sc}$ and $\mathrm{Cr}$; total variance for the first three components $78.1 \%$. Ceramic samples (163 sherds) marked by find region.

Group 2 is dominated by pottery finds from the suspected production site Perkiö (Fig. 2) in inland Finland (Fig. 6), also including ceramics from nearby Uusi-Markkula and Seppälä, sites in coastal Finland (e.g., Kankare, Urheilutie 15, Aisti), and Estonia. The pots in this group show markedly more heterogeneous fabrics 
than the coastal group (Fig. 9), with large grog and mineral inclusions (quartz and K and Na feldspars; $<600$ $\mathrm{mm}$ ) occurring in a mixed, micaceous fabric, suggesting significantly lower levels of clay processing. The high mica content of the Perkiö group pots probably derives from the local varved, silty, and Glacial origin clays and the bedrock composition of granitoids, micaceous gneiss and volcanic rock related to the Svecokarelian orogeny (Al-Ani and Sarapää, 2008: 82; GTK, Bedrock of Finland). The sample set includes one raw clay sample collected near the Perkiö site (fired at 650 [C and prepared as a polished cross-section), which also showed a very micaceous matrix. The clay sample also showed similarity in elemental patterns (e.g., $\mathrm{Ba}, \mathrm{V}$ and $\mathrm{Co}$ ) with the Perkiö group pottery; hence, it provides a link between the local geology and pottery from the site, although not an identical match, as is often the case when comparing raw clays and archaeological pottery, e.g., due to material processing during pottery production (Arnold et al., 1991: 70-71; Wilson and Pollard, 2001: 511). Two of the pots recovered in Estonia (Ruhnu Valgi 60 and Narva-Jõoesuu Ila 2190:607) assigned to this group based on the SEM-EDS data showed a fitting trace elemental profile, e.g., high Co (ca. 600-700 ppm) and V (ca. 1000 ppm) values (Fig. 10). The other Ruhnu sherd (68), however, appears to be an outlier in the trace elemental data set (Fig. 10), and the Veibri pot (5687) shows more Estonian-type trace elemental characteristics.

\begin{tabular}{|c|c|c|c|c|c|c|c|c|c|c|c|c|c|c|c|}
\hline PIXE & & $\mathrm{Fe} \%$ & $\mathrm{Ca} \%$ & $\mathrm{Ti} \%$ & As ppm & Sr ppm & Ba ppm & $\mathrm{V}$ ppm & Zn ppm & Co ppm & Ni ppm & Ge ppm & Sc ppm & Cr ppm & Cu ppm \\
\hline \multirow[t]{2}{*}{ Coastal Finland } & $\mu(n=41)$ & 5.98 & 0.89 & 0.50 & 35 & 114 & 2898 & 982 & 250 & 614 & 131 & 21 & 98 & 76 & 40 \\
\hline & $\sigma$ & 0.73 & 0.34 & 0.09 & 18 & 30 & 609 & 177 & 73 & 105 & 60 & 11 & 35 & 11 & 10 \\
\hline \multirow[t]{2}{*}{ Perkiö } & $\mu(n=17)$ & 7.07 & 0.71 & 0.52 & 50 & 104 & 2889 & 951 & 243 & 692 & 179 & 30 & 68 & 89 & 67 \\
\hline & $\sigma$ & 0.91 & 0.11 & 0.05 & 13 & 16 & 519 & 101 & 57 & 132 & 62 & 21 & 30 & 11 & 19 \\
\hline \multirow[t]{2}{*}{ Kōpu } & $\mu(\mathrm{n}=5)$ & 4.36 & 1.15 & 0.38 & 24 & 148 & 2422 & 728 & 224 & 438 & 70 & 12 & 123 & 57 & 35 \\
\hline & $\sigma$ & 0.62 & 0.23 & 0.06 & 6 & 37 & 410 & 108 & 26 & 73 & 36 & 5 & 20 & 8 & 13 \\
\hline \multirow[t]{2}{*}{ NE Estonia } & $\mu(\mathrm{n}=30)$ & 4.82 & 0.42 & 0.44 & 31 & 83 & 2641 & 794 & 214 & 500 & 89 & 18 & 31 & 61 & 40 \\
\hline & $\sigma$ & 0.54 & 0.12 & 0.05 & 13 & 26 & 462 & 109 & 74 & 61 & 29 & 7 & 20 & 7 & 25 \\
\hline \multirow[t]{2}{*}{ Central Sweden } & $\mu(\mathrm{n}=11)$ & 4.83 & 0.80 & 0.39 & 32 & 107 & 2382 & 773 & 162 & 498 & 63 & 19 & 87 & 61 & 22 \\
\hline & $\sigma$ & 1.50 & 0.19 & 0.06 & 8 & 20 & 359 & 119 & 59 & 170 & 45 & 9 & 27 & 18 & 12 \\
\hline
\end{tabular}

Table 4. PIXE data group mean values $(\mathrm{m})$ and standard divisions (s) for compositional groups 1, 2, 4, 7 and 8, including pottery found to be local to their find regions (coastal Finland, Perkiö, Kõpu, Northeastern Estonia and Central Sweden), based on the SEM-EDS data analysis (results and group assignments for individual samples reported in supplementary data Table 1).

Group 3 (Grog A), the third cluster in the "Finnish" branch of the dendrogram (Fig. 6), includes mainly grog found in Perkiö but also in Estonia (Kõpu I, Ruhnu Valgi and Narva-Jõesuu I) and Sweden (Dunker, Fjälkestad and Vallby), with only a fewsherds recovered at the Finnish sites and at Kõpu. Based on the CA of the SEMEDS data, this group associates geochemically with Finnish groups 1 and 2; hence, it might demonstrate pottery exported from Finland to Sweden and Estonia. However, archaeological interpretations of this group are hindered by its mainly grog members. Exchange patterns indicated by a single sherd/grog sample should also be considered tentative prior to further confirmation.

The majority of the pottery analysed from Kõpu I (Hiiumaa island) on the Estonian coast cluster together in group 4, added by one grog recovered in Narva-Jõesuu lla. The pots show moderately sorted fabrics with abundant temper (grog, quartz, and feldspars; $<700 \mathrm{~mm}$, Fig. 9) and higher Ca and Sc values compared to other samples, suggesting local manufacture at the site. Furthermore, Hiiumaa island is located in a limestone region, rich in $\mathrm{Ca}$ and $\mathrm{Mg}$ (Geological Survey of Estonia; Systra, 2010: 46-47); thus, the higher Ca values (Tables 3 and 4 ) in the Kõpu ceramics are clearly related to the bedrock composition. The Estonian limestones are generally poor in P (Systra, 2010: 47); therefore, the high P values in the samples can be explained by the alkaline environment created by limestones, preventing organic $P$ from leaching, possibly adding to $P$ enrichment from the organic temper (see also group 7). 


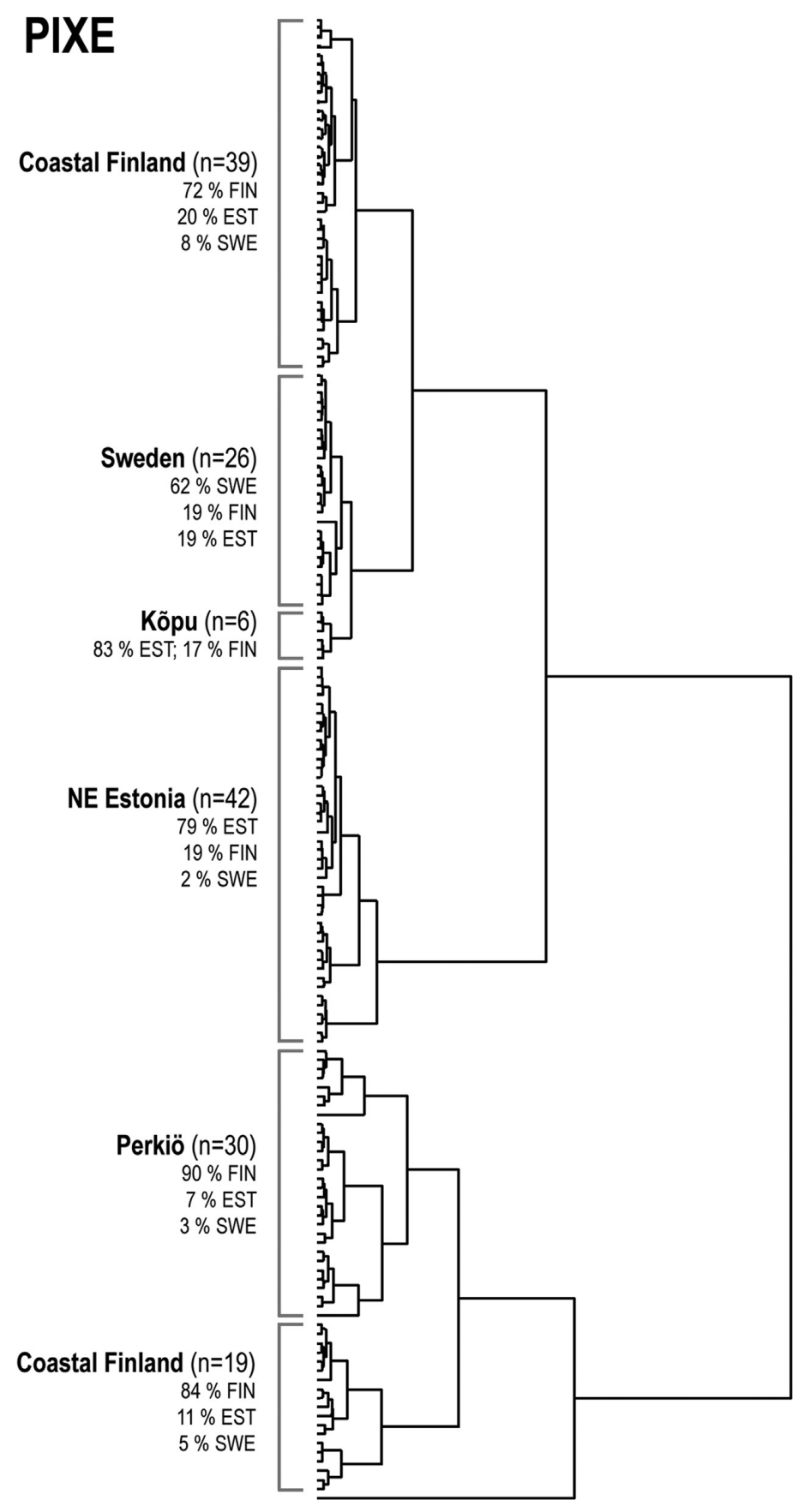

Fig. 8. CA dendrogram of the PIXE ceramic compositional data (163 sherds) showing find-region specific clusters; trace elements $\mathrm{As}, \mathrm{Sr}, \mathrm{V}, \mathrm{Zn}, \mathrm{Co}, \mathrm{Cu}, \mathrm{Ba}$ and $\mathrm{Ni}$.

Group 5 (Grog B) is dominated by grog in Perkiö sherds, including a few sherds from Kankare on the Finnish coast and Veibri in Southeastern Estonia, but this group appears compositionally unrelated, e.g., to the Perkiö group; hence, given the presence of the Veibri pots in this group, it might also represent material links to other (e.g., southern) regions.

Group 6 includes both Swedish (Fjälkestad, Dunker, and Vallby) and Estonian (Narva-Jõesuu I and Ila, Ruhnu Valgi and Kõpu I) samples, added by Perkiö samples. This group cannot be linked to a geographical region with certainty, but there is a geochemical resemblance to Northeastern Estonia-associated group 7. The Perkiö sherd (KM17281:237, Type $\mathrm{F}$ in Finnish CW terminology) in this group presents low Co, $\mathrm{Ni}$, Sc and $\mathrm{V}$ values (at ca. 420, 100, 30, and 740 ppm, respectively) atypical of the Finnish sherds, supporting its Estonian source (Fig. 10). The pots found in Southern Sweden in this group (Fjälkestad 1089877, 1089880, 1089881) 
represent early type $\mathrm{A} / \mathrm{B}$, and display high $\mathrm{Ba}$ and $\mathrm{V}$ concentrations similar to the Estonian sherds (Fig. 11). The sherds recovered in Central Sweden (Vallby 1089866 (Fig. 3), Dunker 1089871 and 415577), which cluster in this group based on the SEM-EDS data, show trace elemental patterns more related to their find region (group 8), leaving their group assignment ambiguous.
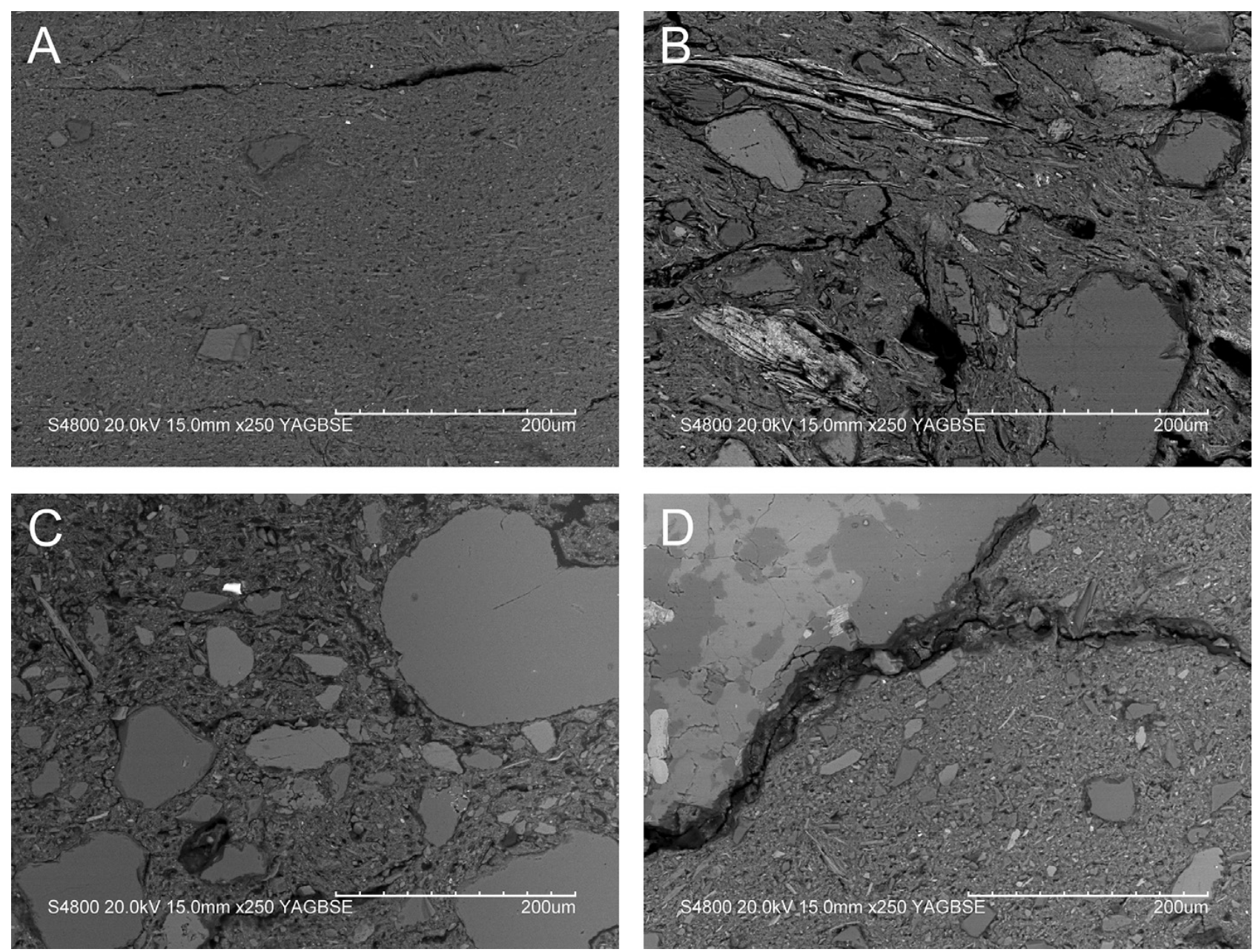

Fig. 9. Backscattered electron images of ceramic fabrics showing: a) a possibly sieved micro-structure with bimodal grain size distribution (group 1, coastal Finland group sample KM21501:151) and more inhomogeneous, less processed fabrics belonging to b) group 2 (Perkiö, sample KM17281:258); c) group 4 (Kõpu) (sample 6007:2624); and d) group 8, Central Sweden (sample 22007:B50).

Most of the sherds analysed from the Estonian sites Narva-Jõesuu I and Ila, and Riigiküla XIV (Fig. 3) cluster together in group 7 (Northeastern Estonia), indicating that these pots originate in this region. Sherds and grog from other Estonian sites, added by Fjälkestad and Dunker in Sweden, and Perkiö in Finland also cluster with this group. The majority of the pots in this group are tempered with organic admixtures (e.g. grass, Fig. 4b), added by grog and sand (quartz, feldspars and mica; 200-500 mm). The fairly wellprocessed ceramic fabrics also show naturally occurring rutile, ilmenite, and garnet group minerals $(<100 \mathrm{~mm})$ and low $\mathrm{Ca}$, Sr and $\mathrm{Sc}$ values ( $<100 \mathrm{ppm}$ ) compared to the other groups, lower $\mathrm{Ni}$, $\mathrm{Co}$ and $\mathrm{V}$ compared to groups 1 and 2 (Fig. 10) and higher Ba compared to group 8 (Fig. 11). The Narva-Jõesuu sites I and Ila are located in a narrow bedrock zone of Cambrian low-Ca sandstones and claystones, between the Baltic Sea and the Ordovician limestones (Donner, 1995: 118, 148e149; Systra, 2010: 46e48). The Fjälkestad pots in this group (1089878, 1089879, 1089882, 415580 and 415581) are well-made beakers (CWC types A/B and D) showing also a fitting trace elemental pattern (e.g., Ba and V higher compared to Swedish group 8, Fig. 11). The Dunker sherd (1089869, Fig. 3), in contrast, shows a more ambiguous trace elemental profile. 


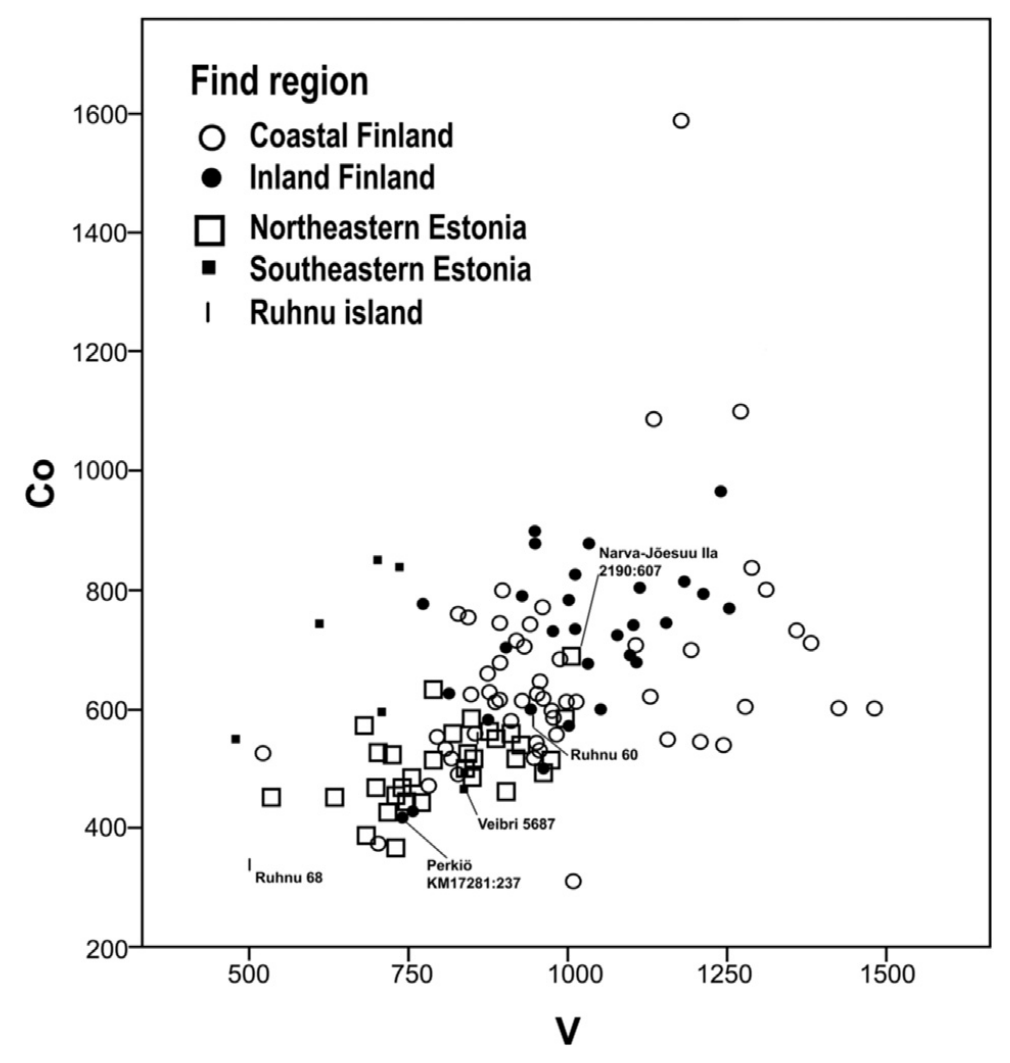

Fig. 10. Biplot of Co and V concentrations measured by PIXE in pottery samples recovered in coastal and inland sites in Finland and the Estonian mainland and Ruhnu island; samples marked by find region.

Group 8 (Central Sweden) includes mainly sherds and grog from central Sweden (Lilla Malma, Dunker, and Vallby, Fig. 3), added by a few sherds and grog from Estonian sites, sites on the Finnish coast and Fjälkestad according to the SEM-EDS data. These pots display more heterogeneous grain-size distribution compared to, e.g., the coastal Finland group, and contain grog, quartz, feldspars and granite with sizes of $300 \mathrm{e} 800 \mathrm{~mm}$ as temper, with the addition of ilmenite, apatite, and garnet group minerals naturally occurring in the clay paste. Group 8 pots show slightly lower $\mathrm{Ba}, \mathrm{Zn}$ and $\mathrm{Ni}$ compared to groups 1, 2 and 7, and lower $\mathrm{V}$ compared to groups 1 and 2 (Fig. 12). The Central Sweden sites are located in a bedrock region belonging to the Svecokarelian orogeny, characterised by metamorphic volcanic rocks (rhyolite and dacite, syenitoids, and schists), and small areas of gabbro and anorthosite, as well as sedimentary rocks (sandstone, siltstone and shale) (SGU, Berggrund 1:1 million). This local environment probably explains the presence of ilmenite (commonly occurs in gabbro and anorthosite), as well as apatite and garnet group minerals (common in pegmatites but absent from the Finnish samples). Pottery recovered in Estonia clustering in this group based on the SEM-EDS data (undecorated, Estonian type CWC sherds Riigiküla XIV 2181:902 and 2181:1318) show high $\mathrm{Ba}$ and $\mathrm{V}$ values not fitting this group. Similarly, the trace elemental data leave the group assignment of the Kõpu I (Al6007: 1667), Ragnvalds (KM22397:356, Fig. 3) and Jönsas (KM19914:594) pots ambiguous. 


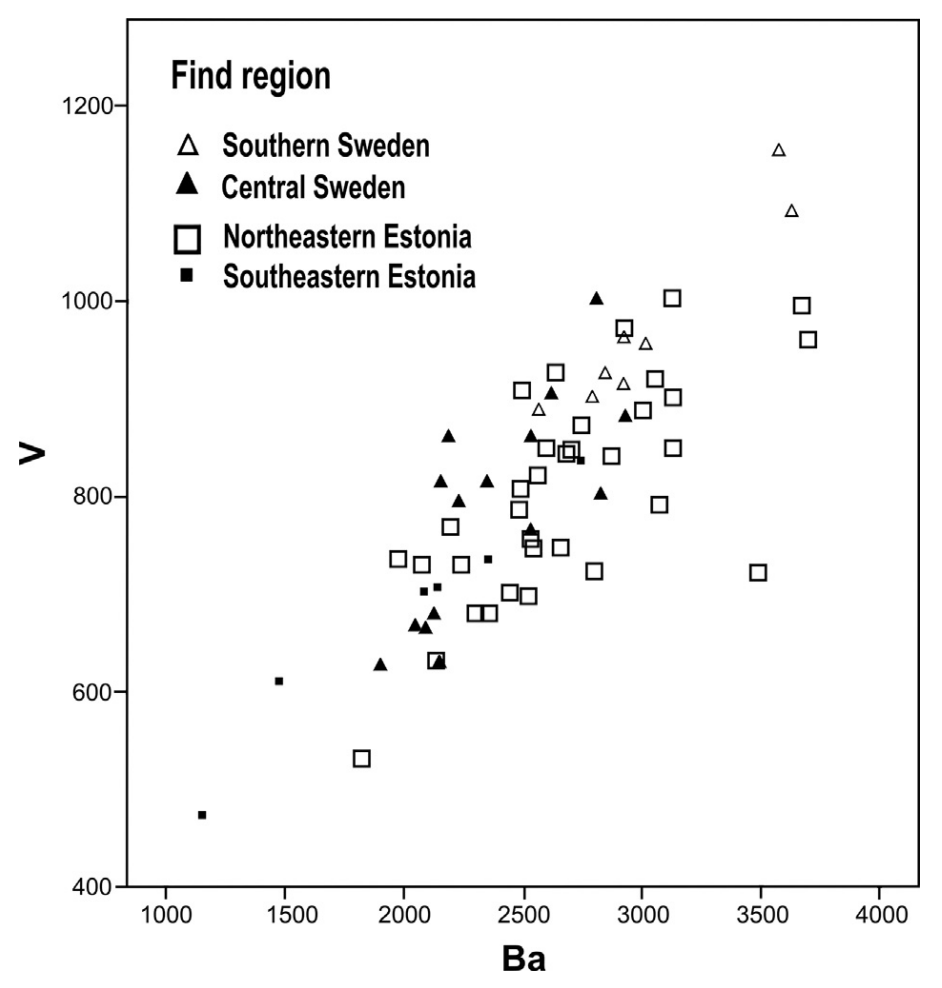

Fig. 11. Biplot of $B a$ and $V$ concentrations measured by PIXE in pottery samples recovered in Sweden and mainland Estonia; samples marked by find region.

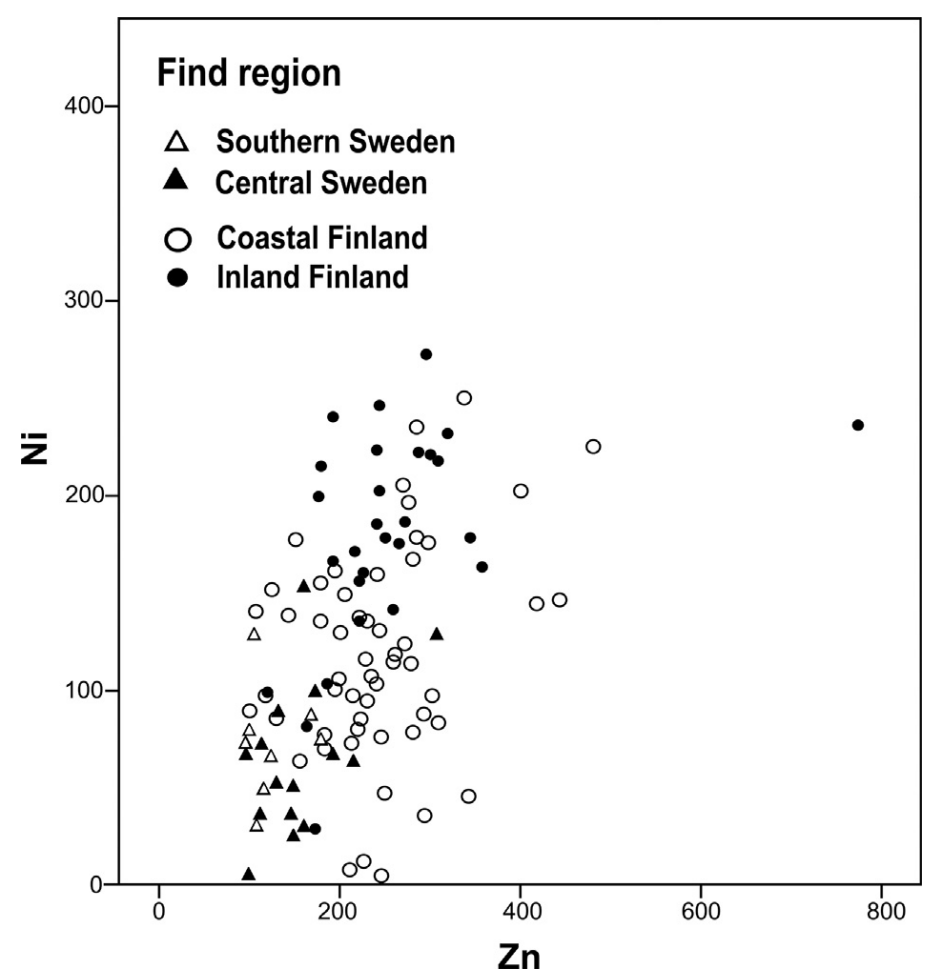

Fig. 12. Biplot of Zn and Ni concentrations in pottery samples recovered in Sweden and Finland measured by PIXE; samples marked by find region.

\section{Conclusions}

The combined SEM-EDS and PIXE analysis of CWC pottery from 24 sites in Finland, Estonia and Sweden indicates a data structure of eight geochemical clusters. At least five of these geochemical groups are 
associated with specific find locations or clusters of sites, indicating that most of the analysed pottery (including grog) was manufactured close to the place where it was discarded and deposited. The geochemical clusters formed by pottery recovered in coastal Finland, Perkiö, Kõpu, Northeastern Estonia and central Sweden can be interpreted as manufacturing regions of the analysed CWC pottery. These groups also show technological variation between them and different methods of clay processing and tempering, emphasising the adaptation of the CWC pottery craft in different environments. Mostly locally manufactured pots were used to temper new ones, although there are also exceptions, e.g., at least three geochemically different grog types were used to temper a Perkiö pot (KM18047:299, Fig. 2). A lineage of grog (i.e., grog-ingrog) was also sometimes present in the pottery fabrics, typically (but not always) all generations belonging to the same (local) manufacturing tradition and geochemical group.

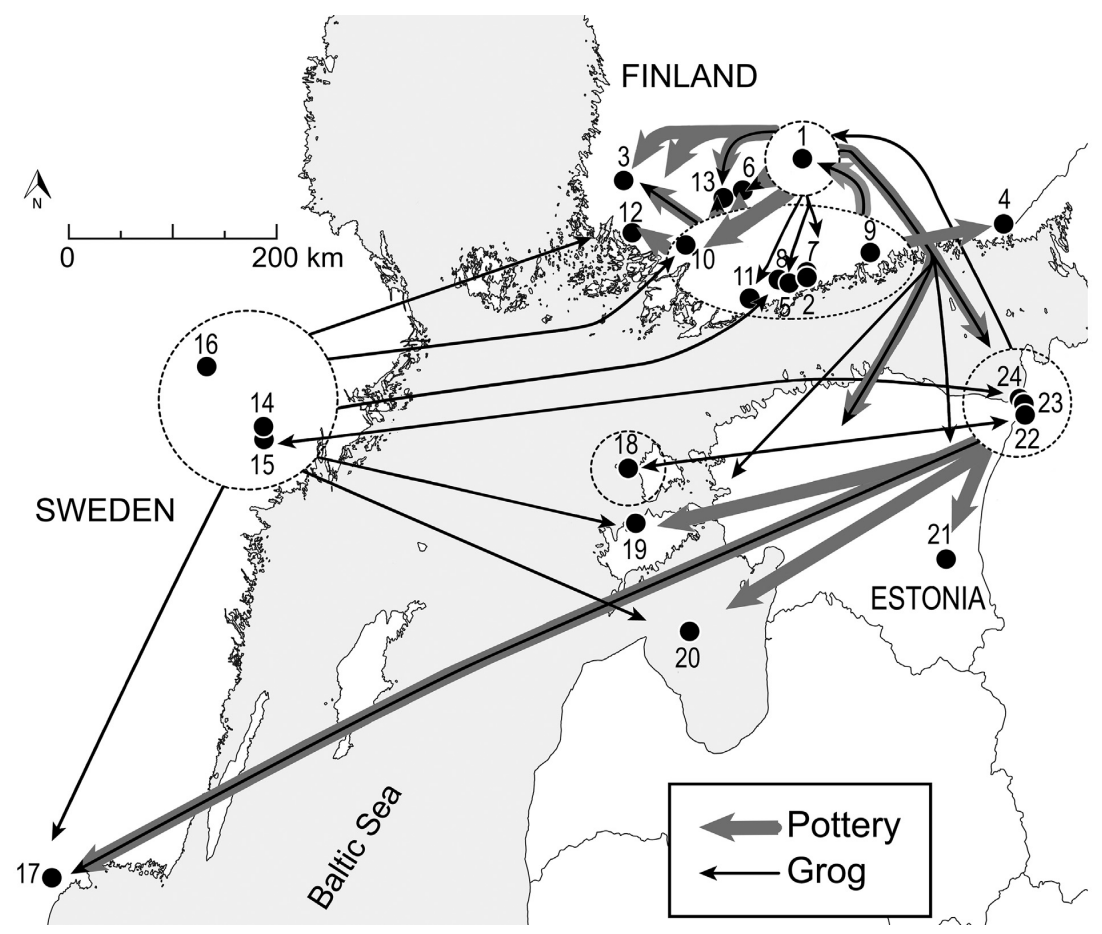

Fig. 13. Five manufacturing regions (circles) and possible exchange patterns indicated by the pottery (grey arrows) and grog (black arrows) geochemical data. Sites: 1) Perkiö; 2) Malminkartano; 3) Aisti; 4) Mattilan VPK; 5) Mäntymäki; 6) Seppälä; 7) Jönsas; 8) Tengo Nyåker; 9) Böle; 10) Urheilutie 15; 11) Ragnvalds; 12) Kankare; 13) Uusi-Markkula; 14) Lilla Malma; 15) Dunker Barsjö; 16) Kil Vallby; 17) Fjälkestad Rötved; 18) Kõpu l; 19) Võhma l; 20) Ruhnu Valgi; 21) Veibri; 22) Narva-J oesuu I; 23) Narva-Jõesuu Ila; 24) Riigiküla XIV.

Some pots and grog link geochemically with a compositional group other than that of their find region, indicating that they are imports, transported from another CWC manufacture region. In our sample set, only $12(7.36 \%)$ of the 163 analysed pots were identified as imports (by both SEM-EDS and PIXE data); hence, it appears that the CWC communities mainly relied on their own ceramic supplies and nearby clay resources. If these communities were relocating, they seem to have brought ready crafting skills applicable in their new environment. There appears to have been cross-Baltic Sea pottery transport, particularly in East-Southwest direction, from Northeastern Estonia to southern Sweden (Fig. 13). The grog data, evidence of the previous generation pots, reinforce these patterns but also highlight additional routes. It is possible that sometimes the grog is the only remaining evidence of these pottery transport actions.

It appears that the early, skillfully made CWC pots found in Sweden were both imported (to Southern Sweden from Northeastern Estonia and possibly Finland) and made with local clays by skilled potters (in Central Sweden). Therefore, it seems probable that at least the first CWC potters relocated to Sweden from a place where the craft was already well established, namely the Eastern part of the Baltic, i.e., Northeastern Estonia and Southern Finland. It is also possible that Swedish origin pots or grog arrived at Finnish and Estonian sites, 
suggesting two-way movement across the Baltic Sea (Fig.13). If we accept the manufacturing site status of Perkiö (no kiln structures or production waste, but exceptionally large quantity of pottery finds), its products appear to have been distributed to nearby sites and also to CWC communities living in the Estonian regions.

There might have been practical reasons for the use of grog as temper - it was certainly a readily available temper material. Ethnographic studies have also shown strong social and symbolic value in the practice of tempering new pots with old ones (Gosselain, 1999; Gosselain and Livingstone Smith, 2005; Pikirayi

and Lindahl, 2013; Smith, 1989; Sterner, 1989). It might be that the foreign grog represents traces of potters who arrived at a new home (e.g., due to migration or marriage), with their personal ceramic utensils. These beakers were later recycled as temper in new ones, as a way of keeping a symbolic connection with past generations and the Corded Ware community at large (see discussion in Larsson, 2009: 351-355, 399-400). One can neither exclude the possibility that the pots were transported as containers of other (agricultural?) products, and the complexity of the ceramic networks should be considered when interpreting other ceramic-related data. For instance, ceramic materials from Tengo Nyåker, a site also sampled by Cramp et al. (2014) for their lipid study, were divided into four geochemical groups representing ceramics likely manufactured in different locations in Finland and Sweden.

Methodologically, we evaluated the challenges and potentials of geochemical discrimination of grogtempered archaeological ceramics. Successful geochemical discrimination of ceramic fabrics using SEM-EDS has also been demonstrated previously and with grog-tempered fabrics (Holmqvist et al., 2014; Spataro, 2011; Zuluaga et al., 2011), yet a high-sensitivity method, such as PIXE, complements the SEM-EDS analysis by extending the elemental variety available for data interpretation and group assignments. The SEM-EDS and PIXE data sets show clear correlation in the data patterns (e.g., correlation coefficient R for SEM-EDS/PIXE measured $\mathrm{CaO} / \mathrm{Ca}$ and $\mathrm{FeO} / \mathrm{Fe}$ was 0.7 and 0.8 , respectively, elements lighter than $\mathrm{Ca}$ were not measured with PIXE; see Fig. 1 in the supplementary data for a large graphical representation of the similarities of the SEM-EDS and PIXE results across the samples). However, a careful evaluation of the different data sets and especially the elements significant for geochemical discrimination is required to formulate meaningful archaeological interpretations. The inconsistencies, e.g., trace elemental data conflicting with the SEMEDS group assignments of individual samples, most likely derive from accuracy issues related to the SEM-EDS analysis and temper interference in the PIXE results caused by inhomogeneous ceramic samples. This approach could be further developed using a high-accuracy technique that allows for more detailed focusing of the beam and visual identification of the analysed area, such as LA-ICPMS. Micro-structural and technological differences in the ceramic fabrics, identifiable by SEM-EDS, can aid confirming geochemical group discrimination, especially between geochemically related groups (e.g., coastal Finland and Perkiö groups).

The results of this multi-site project revealed manufacturing regions of the CWC pottery and a complex, crossBaltic Sea pottery exchange phenomenon during the third millennium BCE, illustrated by archaeological ceramics and grog temper. It is particularly useful to consider the grog factor in cases in which evidence for exchange appears scarce in the ceramic assemblages, but the cultural context and other evidence (e.g., DNA and stable isotopes) imply cultural transitions, extensive contact or migration.

\section{Acknowledgements}

This research was funded by the Academy of Finland [grant number 257395] project Untangling Corded Ware: Provenancing Neolithic Battle Axe Culture Pottery of Southern Finland. This project was also supported by the Emil Aaltonen Foundation, Berit Wallenberg Foundation (2012.0099) Magnus Ehrnrooth Foundation, and Estonian Research Council project "Estonia in Circum-Baltic space: Archaeology of economic, social, and cultural processes". The authors wish to thank the three anonymous reviewers for their insights and comments on an earlier version of this paper, and the following institutions and individuals: The Finnish National Board of Antiquities, the Swedish History Museum, Archaeological Research Collection of Tallinn University, Kent Andersson, Päivi Kankkunen. Marianna Kemell, Valter Lang, Mika Lavento, Kristiina 
Mannermaa, Tuomas Nissinen, Kerkko Nordqvist, Markku Oinonen, Sara Perälä, Päivi Pykälä-Aho, Marja Siitari-Kauppi, and Jackie Taffinder.

\section{References}

Al-Ani, T., Sarapää, O., 2008. Clay and Clay Mineralogy. Physicalechemical Properties and Industrial Uses. Geologian Tutkimuskeskus. M19/3232/2008/41.

Allentoft, M.E., Sikora, M., Sjögren, K.G., Rasmussen, S., Rasmussen, M., Stenderup, J., Damgaard, P.B., Schroeder, H., Ahlström, T., Vinner, L., Malaspinas, A.S., Margaryan, A., Higham, T., Chivall, D., Lynnerup, N., Harvig, L., Baron, J., Della Casa, P., Da cbrowski, P., Duffy, P.R., Ebel, A.V., Epimakhov, A., Frei, K., Furmanek, M., Gralak, T., Gromov, A., Gronkiewicz, S., Grupe, G., Hajdu, T., Jarysz, R., Khartanovich, V., Khokhlov, A., Kiss, V., Kol_a_r, J., Kriiska, A., Lasak, I., Longhi, C., McGlynn, G., Merkevicius, A., 2015. Population genomics of bronze age Eurasia. Nature 522, 167-172.

Alvarez Romero, J., 2010. People of the corded ware culture in the east Baltic region, Lithuania. Tyragetia 4, 139-147.

Arnold, D.E., Neff, H., Bishop, R.L., 1991. Compositional analysis and "sources" of pottery: an ethnoarchaeological approach. Am. Anthropol. 93, 70-90.

Baxter, M.J., Buck, C.E., 2000. Data handling and statistical analysis. In: Ciliberto, E., Spote, G. (Eds.), Modern Analytical Methods in Art and Archaeology. Wiley, Chichester, pp. 681-746.

Baxter, M.J., Freestone, I.C., 2006. Log-ratio compositional data analysis in archaeometry. Archaeometry $48,511-531$.

Beckerman, S.M., 2015. Corded Ware Coastal Communities. Using Ceramic Analysis to Reconstruct Third Millennium BC Societies in the Netherlands. PhD Thesis. University of Groningen. Sidestone Press, Leiden.

Bishop, R.L., Canouts, V., Crown, P.L., De Atley, S.P., 1990. Sensitivity, precision, and accuracy: their roles in ceramic compositional data bases. Am. Antiq. 55, 537-546.

Brink, K., 2009. I Palissadernas Tid. Om Stolphål Och Skärvor Och Sociala Relationer under Yngre Mellanneolitikum. Malmö Museer, Arkeologienheten.

Bronk Ramsey, C., 2009. Bayesian analysis of radiocarbon dates. Radiocarbon 51, 337-360.

Bronk Ramsey, C., 2010. OxCal 4.1 Calibration Programme. http://c14.arch.ox.ac.uk/

Buxeda I Garrigós, J., Cau Ontiveros, M.A., Kilikoglou, V., 2003. Chemical variability in clays and pottery from a traditional cooking pot production village: testing assumptions in Pereuela. Archaeometry 45, $1-17$.

Carpelan, C., 1999. Käännekohtia Suomen esihistoriassa aikavälillä 5100-1000 eKr. In: Fogelberg, P. (Ed.), Pohjan Poluilla. Suomalaisten Juuret Nykytutkimuksen Mukaan. Bidrag till Kännedom Av Finlands Natur Och Folk. Suomen Tiedeseura, pp. 249-280.

Carpelan, C., 2004. Corded ware culture in northern Finland. Early in the North 5 (Iskos 13), 47-62. 
Carpelan, C., 2006. On archaeological aspects of uralic, finno-ugric and finnic Societies before AD 800. Slavica Helsingiensia 27, 78-92.

Cramp, L.J.E., Evershed, R.P., Lavento, M., Halinen, P., Mannermaa, K., Oinonen, M., Kettunen, J., Perola, M., Onkamo, P., Heyd, V., 2014. Neolithic dairy farming at the extreme of agriculture in northern. Europe. Proc. Biol. Sci. 281, 20140819 https://doi.org/10.1098/rspb.2014.0819.

Czebreszuk, J., 2004. Corded Ware from east to west. In: Bogucki, P.I., Crabtree, P.J. (Eds.), Ancient Europe, 8000 B.C. To A.D. 1000: Encyclopedia of the Barbarian World. Thomson Gale, New York, pp. 467-475.

Donner, J., 1991. Suomen Kvartäärigeologia. Helsingin yliopisto, Geologian laitos, Geologian ja paleontologian osasto, moniste 1. 5., korjattu painos. Yliopistopaino, Helsinki.

Donner, J., 1995. The Quaternary History of Scandinavia. World and Regional Geology, vol. 7. University Press, Cambridge NY.

Edgren, T., 1959. Eknäs-graven. Ett Bidrag till Kännedomen Om Båtyxkulturen I Östra Nyland. Finskt Museum LXX, pp. 27-51.

Edgren, T., 1970. Studier över den snörkeramiska kulturens keramik i Finland. Suomen Muinaismuistoyhdistyksen Aikakauskirja. Suomen Muinaismuistoyhdistys 72.

Edgren, T., 1993. Den förhistoriska tiden. Finlands Historia, Schildts, Espoo, pp. 9-270.

Freestone, I.C., 1982. Applications and potential of electron probe micro-analysis in technological and provenance investigations of ancient ceramics. Archaeometry 24, 99-116.

Furholt, M., 2003. Absolutchronologie und die Entstehung der Schnurkeramik. J. Neolithic Archaeol. https://doi.org/10.12766/jna.2003.7.

Geological survey of Estonia, 2010. Eesti Geoloogiakeskus. Bedrock Geological Map of Estonia 1 (100000). http://www.egk.ee/wp-content/uploads/2011/05/Mapesileht- landscape.pdf. (Accessed 27 June 2017). http://www.egk.ee/wpcontent/ uploads/2011/05/Map-teineleht-portrate.pdf.

Gosselain, O.P., 1999. In pots we trust: the processing of clay and symbols in Sub-Saharan Africa. J. Mater. Cult. 4, 205-230.

Gosselain, O.P., Livingstone Smith, A., 2005. The source. Clay selection and processing practices in subSaharan Africa. In: Smith, A.L., Bosquet, D., Martineau, R. (Eds.), Pottery Manufacturing Processes: Reconstitution and Interpretation, pp. 33-47. BAR International Series 1359.

GTK, Geologian Tutkimuskeskus. Bedrock of Finland, http://gtkdata.gtk.fi/ Kalliopera/index.html (accessed 27.6.2017).

Haak, W., Lazaridis, I., Patterson, N., Rohland, N., Mallick, S., Llamas, B., Brandt, G., Nordenfelt, S., Harney, E., Stewardson, K., Fu, Q., Mittnik, A., B_anffy, E., Economou, S., Francken, M., Friederich, S., Pena, R.G., Hallgren, F., Khartanovich, V., Khokhlov, A., Kunst, M., Kuznetsov, P., Meller, H., Mochalov, O., Moiseyev, V., Nicklisch, N.,Pichler, S.I., Risch, R., Rojo Guerra, M.A., Roth, C., Szécsényi-Nagy, A., Wahl, J., Meyer, M., Krause, J., Brown, D., Anthony, D., Cooper, A., Alt, K.W., Reich, D., 2015. Massive migration from the steppe was a source for Indo-European languages in Europe. Nature 522, 207e211. https://doi.org/10.1038/nature14317. 
Hansen, F., 1930. En nyfunnen skånsk markgrav från stenåldern. Fornvännen 25, 129-135.

Holmqvist, V.E., 2010. Ceramics in Transition: a Comparative Analytical Study of Late Byzantineeearly Islamic Pottery in Southern Transjordan and the Negev. Unpublished PhD Thesis. Institute of Archaeology, University College London.

Holmqvist, E., Väisänen, R., Koivisto, A., 2014. Redwares from Gubbacka's medieval village: regional and inter-regional views on ceramic networks and technology (SEM-EDS). Estonian J. Near E. Archaeol. $18,86-101$.

Hüls, C.M., Erlenkeuser, H., Nadeau, M., Grootes, P.M., Andersen, N., 2010. Experimental study on the origin of cremated bone apatite carbon. Radiocarbon 52, 587-599.

Jungner, H., Sonninen, E., 1983. Radiocarbon Dates II. Report 2. Radiocarbon Dating Laboratory, University of Helsinki, Helsinki.

Korsman, K., Koistinen, T., 1998. Suomen Kallioperän Yleispiirteet. In: Lehtinen, M., Nurmi, P., Rämö, T. (Eds.), Suomen Kallioperä. Suomen Geologinen Seura ry, 3000 vuosimiljoonaa. Helsinki.

Kriiska, A., 2000. Corded ware culture sites in North-eastern Estonia. In: Jaanits, L., Lang, V. (Eds.), De Temporibus Antiquissimis Ad Honorem Lembit Jaanits. Muinasaja Teadus, Tallin, vol. 8, pp. 59-79.

Kriiska, A., 2003. From hunter-fisher-gatherer to farmer: changes in the Neolithic economy and settlement on Estonian territory. Archaeol. Lithuana 4, 11-26.

Kriiska, A., 2009. The beginning of farming in the eastern Baltic. In: Dolukhanov, P.M., Sarson, G.R., Shukurov, A.M. (Eds.), The East European Plain on the Eve of Agriculture. Archaeopress, Oxford, pp. 159-179. BAR International Series 1964.

Kriiska, A., Lõugas, L., Lõhmus, M., Mannermaa, K., Johanson, K., 2007. New AMS dates from Estonian stone age burial sites. Estonian J. Archaeol 11, 83-121.

Kriiska, A., Nordqvist, K., Gerasimov, D.V., Sandel, S., 2015. Preliminary results of the research at Corded Ware sites in the NarvaeLuga interfluve, Estonian-Russian border area in 2008e2014. Archaeological Fieldwork in Estonia 2014, 39-50.

Kriiska, A., Gerasimov, D.V., Nordqvist, K., Lisitsyn, S.N., Sandel, S., Kholkina, M.A., 2016. Stone age research in the Narva-Luga Klint bay area in 2005e2014. In: New Sites, New Methods, Proceedings of the Finnish-Russian Archaeological Symposium, Helsinki, 19-21 November, 2014. Iskos 11, pp. 101-115.

Kristiansen, K., Allentoft, M.E., Frei, K.M., Iversen, R., Johannsen, N.N., Kroonen, G., Pospieszny, t., Price, T.D., Rasmussen, S., Sjögren, K.-G., Sikora, M.,Willerslev, E., 2017. Re-theorising mobility and the formation of culture and language among the Corded Ware Culture in Europe. Antiquity 91, 334-347.

Lang, V., Kriiska, A., 2007. The final Neolithic and early bronze age contacts between Estonia and Scandinavia. In: Fransson, U., Svedin, M., Bergerbrant, S., Androshchuk, F. (Eds.), Cultural Interaction between East and West: Archaeology, Artefacts and Human Contacts in Northern Europe. Stockholm University, Stockholm, pp. 107-112.

Larsson, Å.M., 2008. The hand that makes the pot. Craft traditions in south Sweden in the third millennium BC. In: Berg, I. (Ed.), Breaking the Mould: Challenging the Past through Pottery. Prehistoric Ceramics Research Group, pp. 81-91. Occasional Paper 6. BAR International Series 1861. 
Larsson, Å.M., 2009. Making and Breaking Bodies and Pots. Material and Ritual Practices in Sweden in the Third Millennium BC. Department of Archaeology and Ancient History. Uppsala University, Uppsala.

Lazaridis, I., Patterson, N., Mittnik, A., Renaud, G., Mallick, S., Kirsanow, K., Sudmant, P.H., Schraiber, J.G., Castellano, S., Lipson, M., Berger, B., Economou, C., Bollongino, R., Fu, Q., Bos, K.I., Nordenfelt, S., Li, H., de Filippo, C., Prüfer, K., Sawyer, S., Posth, C., Haak, W., Hallgren, F., Fornander, E., Rohland, N., et al., 2014. Ancient human genomes suggest three ancestral populations for presentday Europeans. Nature 513, 409-413. https://doi.org/10.1038/nature13673.

Leskinen, S., Pesonen, P., 2008. Vantaan Esihistoria. Vantaan Kaupunki.

Lindström, J., 2003. Long distance distribution of battle axes in Northern Europe - some aspects of the contacts between Denmark, Sweden and Finland 2008- 2003 BC. In: Samuelsson, C., Ytterberg, N. (Eds.), Uniting Sea e Stone Age Societies in the Balric Sea Region. Uppsala University, pp. 147-160. OPIA 33.

Lõugas, L., Kriiska, A., Maldre, L., 2007. New dates for the Late Neolithic corded Ware culture burials and early husbandry in the east Baltic region. Archaeofauna 16, 21-31.

Malmer, M.P., 1962. Jungneolithische Studien. Lund University, Department of Archaeology, Lund.

Malmer, M.P., 2002. The Neolithic of South Sweden. TRB, GRK, and STR. The Royal Swedish Academy of Letters History and Antiquities, Stockholm.

Malmström, H., Linderholm, A., Skoglund, P., Storå, J., Sjödin, P., Gilbert, M.T., Holmlund, G., Willerslev, E., Jakobsson, M., Liden, K., Götherström, A., 2015. Ancient mitochondrial DNA from the northern fringe of the Neolithic farming expansion in Europe sheds light on the dispersion process. Philos. Trans. $R$. Soc. Lond., B. Biol. Sci. 370, 20130373 https://doi.org/10.1098/rstb.2013.0373.

Mathieson, I., Lazaridis, I., Rohland, N., Mallick, S., Patterson, N., Roodenberg, S.A., Harney, E., Stewardson, K., Fernandes, D., Novak, M., Sirak, K., Gamba, C., Jones, E.R., Llamas, B., Dryomov, D., Pickrell, J., Arsuaga, J.L., Bermúdez de Castro, J.M., Carbonell, E., Gerritsen, F., Khokhlov, A., Kuznetsov, P., Lozano, M., Meller, H., Mochalov, O., Moiseyev, V., Rojo Guerra, M.A., Roodenberg, J., Verg_es, J.M., Krause, J., Cooper, A., Alt, K.W., Brown, D., Anthony, D., Lalueza-Fox, C., Haak, W., Pinhasi, R., Reich, D., 2015. Eight thousand years of natural selection in Europe. BioRxi March 2015. https://doi.org/10.1101/016477.

Mökkönen, T., 2008. A review of Neolithic multi-room housepits as seen from the Meskäärtty site in Virolahti parish, extreme south-eastern Finland. Estonian J. Archaeol. 12, 114-151.

Mökkönen, T., 2011. Studies on Stone Age Housepits in Fennoscandia (4000-2000 CalBC). Changes in Ground Plan, Site Location, and Degree of Sedentism, Helsinki.

Nordqvist, K., 2016. From separation to interaction. Corded ware in the eastern Gulf of Finland. Acta Archaeol. 87 (1), 49-84.

Nordqvist, K., Häkälä, P., 2014. Distribution of the corded ware in the areas North of the Gulf of Finland an update. Estonian J. of Arch. 8 (1), 3-29.

Ojonen, S., 1983. Vantaan Myyrmäen Jönsaksen radiohiiliajoitukset v. 1975-77. Karhunhammas 7, 14-20. 
Olsen, J., Heinemeier, J., Horsnstrup, K.M., Bennike, P., Thrane, H., 2012. 'Old Wood' effect in radiocarbon dating of prehistoric cremated bones? J. Archaeol. Sci. 40, 30-34.

Palonen, V., Tikkanen, P., 2015. A novel upgrade to Helsinki AMS: fast switching of isotopes with electrostatic deflectors. Nucl. Instrum. Methods Phys. Res. B Beam Interact. Mater. Atoms 361, $263-$ 266. https://doi.org/10.1016/j.nimb.2015.04.053.

Palonen, V., Mizohata, K., Nissinen, T., Räisänen, J., 2016. External beam IBA set-up with large-area thin Si3N4 window. Nucl. Instrum. Methods Phys. Res. B Beam Interact. Mater. Atoms 380, 11-14.

Pesonen, P., Oinonen, M., Carpelan, C., Onkamo, P., 2012. Early subneolithic ceramic sequences in eastern fennoscandia - a Bayesian approach. Radiocarbon 54, 661-676.

Pikirayi, I., Lindahl, A., 2013. Ceramics, ethnohistory, and ethnography: locating meaning in southern African Iron Age ceramic assemblages. Afr. Archaeol. Rev. 30, 455-473.

Piličiauskas, G., Lavento, M., Oinonen, M., Gri_zas, G., 2011. New 14C dates of Neolithic and Early metal period ceramics in Lithuania. Radiocarbon 53, 629-643.

Purhonen, P., 1986. Vantaan Jönsaksen nuorakeraamiset haudat. Iskos 6, 113-125.

Reimer, P.J., Bard, E., Bayliss, A., Beck, J.W., Blackwell, P.G., Bronk Ramsey, C., Grootes, P.M., Guilderson, T.P., Haflidason, H., Hajdas, I., Hatt_e, C., Heaton, T.J., Hoffmann, D.L., Hogg, A.G., Hughen, K.A., Kaiser, K.F., Kromer, B., Manning, S.W., Niu, M., Reimer, R.W., Richards, D.A., Scott, E.M., Southon, J.R., Staff, R.A., Turney, C.S.M., van der Plicht, J., 2013. IntCal13 and marine13 radiocarbon age calibration curves 0-50,000 years cal BP. Radiocarbon 55, 1869-1887.

Rizzutto, M.A., Tabacniks, M.H., 2017. Particle induced X-ray emission (PIXE) and its applications for ceramic analysis. In: Hunt, A.W. (Ed.), The Oxford Handbook of Archeological Ceramic Analysis. Oxford University Press, Oxford, pp. 282-398.

Salonen, V.-P., Eronen, M., Saarnisto, M., 2002. Käytännön Maaperägeologia. Kirja-Aurora, Turku.

Schwedt, A., Mommsen, H., zacharias, N., 2004. Post-depositional elemental alterations in pottery: neutron activation analyses of surface and core samples. Archaeometry 46, 85-101.

SGU, Sveriges Geologiska Undersökning. Berggrund 1:1 miljon. URL: https://apps. sgu.se/kartvisare/kartvisare-berggrund-1-miljon.html. Accessed 27.6.2017.

Sjögren, K.G., Price, T.D., Kristiansen, K., 2016. Diet and mobility in the corded ware of Central Europe. PLos One 11, e0155083. https://doi.org/10.1371/journal.pone.0155083.

Skoglund, P., Malmström, H., Omrak, A., Raghavan, M., Valdiosera, C., Günther, T., Hall, P., Tambets, K., Parik, J., Sjögren, K.G., Apel, J., Willerslev, E., Storå, J., Götherström, A., Jakobsson, M., 2014. Genomic diversity and admixture differs for stone-age Scandinavian foragers and farmers. Science 344, 747-750. https://doi.org/10.1126/science.1253448.

Smith, F.T., 1989. Earth, vessels, and harmony among the Gurensi. Afr. Arts 22, 60-65.

Spataro, M., 2011. A comparison of chemical and petrographic analyses of Neolithic pottery from Southeastern Europe. J. Archaeol. Sci. 38, 255-269. 
Sterner, J., 1989. Who is signalling whom? Ceramic style, ethnicity and taphonomy among the Sirak Bulahay. Antiquity 63, 451-459.

Sundell, T., 2014. The Past Hidden in Our Genes. Combining Archaeological and Genetic Methodology: Prehistoric Population Bottlenecks in Finland. Ph.D. Dissertation. University of Helsinki, Helsinki.

Systra, Y.J., 2010. Forestry studies. Metsanduslikud Uurim. 53, 35-52.

van Strydonck, M.V., Boudin, M., de Mulder, G.D., 2010. The carbon origin of structural carbonate in bone apatite of cremated bones. Radiocarbon 52, 578-586.

Vuorisalo, T., Arjamaa, O., Vasemägi, A., Taavitsainen, J.P., Tourunen, A., Saloniemi, I., 2012. High lactose tolerance in North Europeans: a result of migration, not in situ milk consumption. Perspect. Biol. Med. 55, 163-174.

Wilson, L., Pollard, A.M., 2001. The provenance hypothesis. In: Brothwll, D.R., Pollard, A.M. (Eds.), Handbook of Archaeological Sciences. Wiley, Chichester, pp. 507-517.

Włodarczak, P., 2009. Radiocarbon and dendrochronological dates of the corded ware culture. Radiocarbon 51, 737-749. https://doi.org/10.1353/pbm.2012.0016.

Zuluaga, M.C., Alonso-Olazabal, A., Murelaga, X., Ortega, L.A., 2011. A comparison of scanning electron microscopy energy dispersive X-ray (SEM/EDX) and inductively coupled plasma optical emission spectrometry (ICP-OES) for provenance inferences of grog-tempered Bronze Age pottery. Microchem. J. 99, 443-448. 